Portland State University

PDXScholar

$5-4-1981$

\title{
Characteristics and Practices of Forensics Programs in Oregon Secondary Schools
}

\author{
Gregg T. Sylvester \\ Portland State University
}

Follow this and additional works at: https://pdxscholar.library.pdx.edu/open_access_etds

Part of the Education Commons, Forensic Science and Technology Commons, and the Speech

Pathology and Audiology Commons

Let us know how access to this document benefits you.

\section{Recommended Citation}

Sylvester, Gregg T., "Characteristics and Practices of Forensics Programs in Oregon Secondary Schools" (1981). Dissertations and Theses. Paper 3097.

https://doi.org/10.15760/etd.3092

This Thesis is brought to you for free and open access. It has been accepted for inclusion in Dissertations and Theses by an authorized administrator of PDXScholar. Please contact us if we can make this document more accessible: pdxscholar@pdx.edu. 
AN ABSTRACT OF THE THESIS OF Gregg $T$. Sylvester for the Master of Science in Speech Communication presented May 4, 1981.

Title: Characteristics and Practices of Forensics Programs in

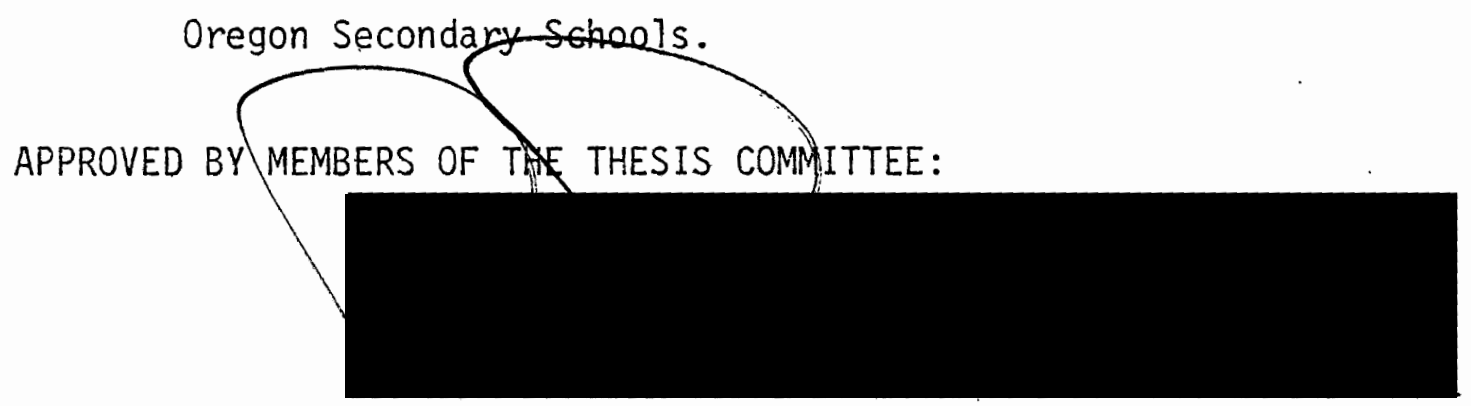

Ben Padrow, Chairman
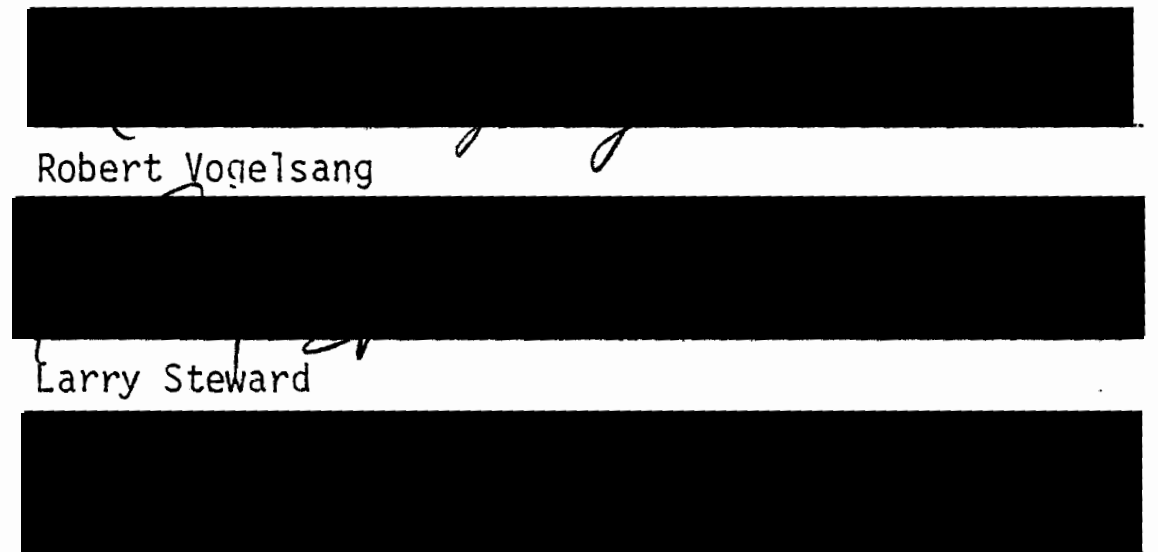

Richard Lindner

Since 1943, six studies have been made of speech education in Oregon public schools. Several make reference to forensics, but none discuss this aspect of speech education in depth. As a result, the role of forensics in the schools has been assumed or denied. With the educational situation as $i t$ is, however, it is necessary 
that we have a greater understanding of the relationship between forensics and general speech education and language arts education.

This study seeks to provide contemporary information on forensics programs which may be useful in examining this relationship. Included in the study are: 1) the nature and scope of forensics programs, 2) the characteristics and qualifications of forensics directors, and 3) the characteristics of forensics students.

Questionnaires were sent to all member schools of the Oregon High School Speech League. The results of the 19.77 and 1980 surveys provide the basis for discussion. The results are compared to note. changes between the two years and the possible causes for these changes. Relationships which may exist among program characteristics are aiso considered.

The results of the study indicate that forensics programs in Oregon secondary schools have stabilized. Large programs, both in terms of the the number of participants and budgets, have been eliminated. In the same categories, very small programs have grown. The average program is now budgeted at between two and three thousand dollars, enabling eighteen students to participate in nine forensics tournaments.

While forensics is a competitive activity, the goals of programs, as indicated by forensics directors, do not emphasize this. The most important goal was felt to be the promotion of the personal growth of students. The least important of the ten goals was the improvement of public speaking skills. 
Of the survey results, the most marked change occurs in the area of forensics directors. Fewer coaches have bachelor's or master's degrees in speech communication, and more do not even have a norm of fifteen quarter hours in speech as part of their teaching certificate. This can be attributed to the fact that coaches primarily. teach in the English departments of their respective schools. After one year of coaching, directors tend to change their school affiliation to their present one, where they have been for five years. A director receives an average of $\$ 846.00$ in extra-duty compensation for handling the forensics program.

It is possible that changes in survey results are attributable to two principal factors--the economic situation of schools and the Oregon language arts teaching certificate. The economic situation is reflected in budgets which directly or indirectly influence the number of students who can participate and the number of tournaments. The language arts teaching certificate permits non-speech teachers to direct forensics programs, thereby influencing the strength of programs in terms of the quality of performance and the types of forensics events stressed at the schools.

Much of the value of the present study lies in the knowledge that the results may be used as a starting point for further investigations into the status of Oregon high school forensics programs. Research is needed to determine the attitudes of various groups toward forensics, the influence of the forensic director on the emphasis of the program, and the reasons for the comparative success or failure 
of forensics programs. When adequate information becomes available, the proper role of forensics as an integral part of speech communication education in Oregon secondary schools will be able to be fulty determined. 


\title{
CHARACTERISTICS AND PRACTICES OF FORENSICS PROGRAMS IN OREGON
} SECONDARY SCHOOLS

\author{
by \\ GREGG T. SYLVESTER
}

A thesis submitted in partial fulfillment of the requirements for the degree of

\author{
MASTER OF SCIENCE \\ in \\ SPEECH COMMUNICATION
}

Portland State University

1981 
TO THE OFFICE OF GRADUATE STUDIES AND RESEARCH:
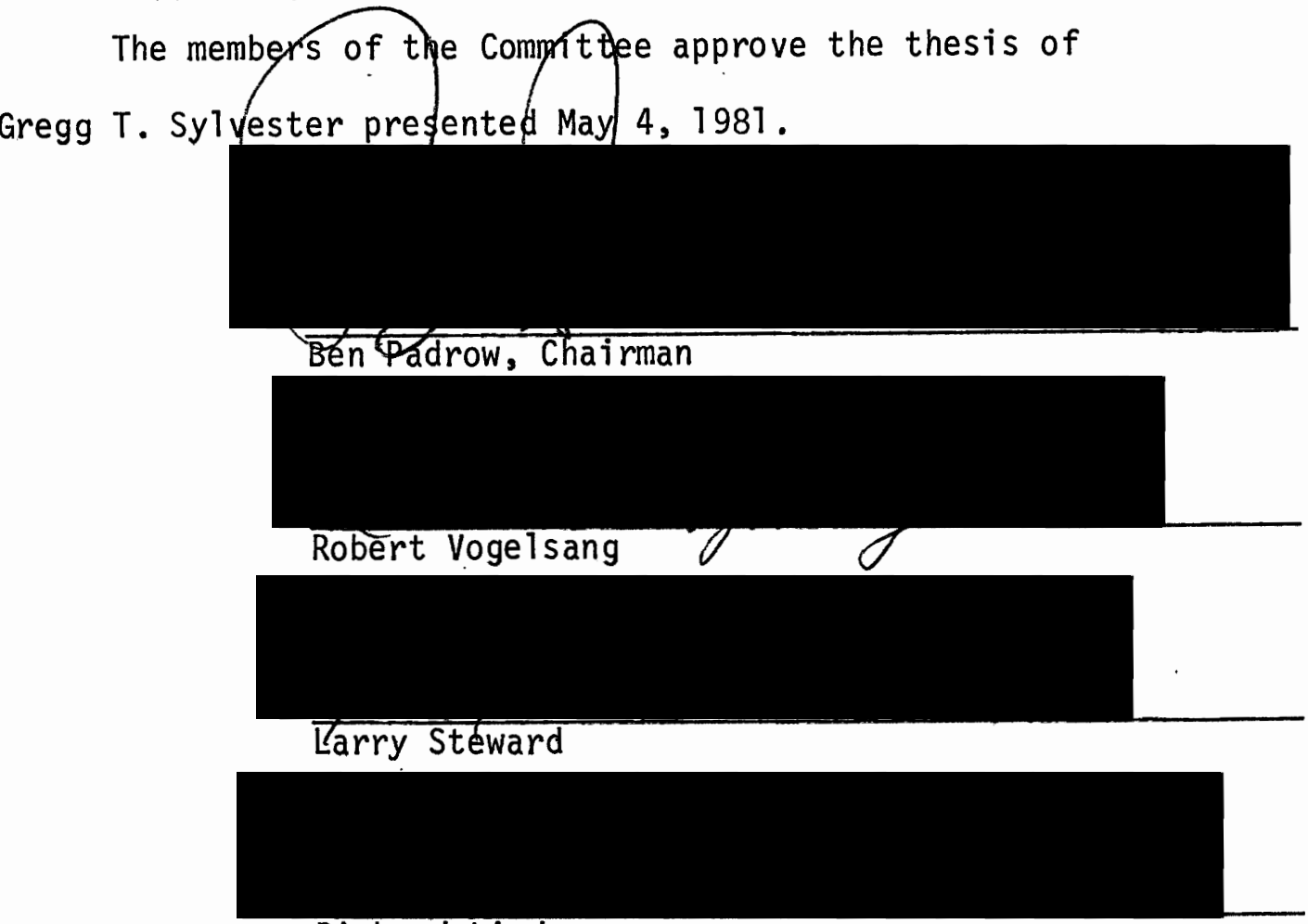

Richard Lindner

APPROVED:

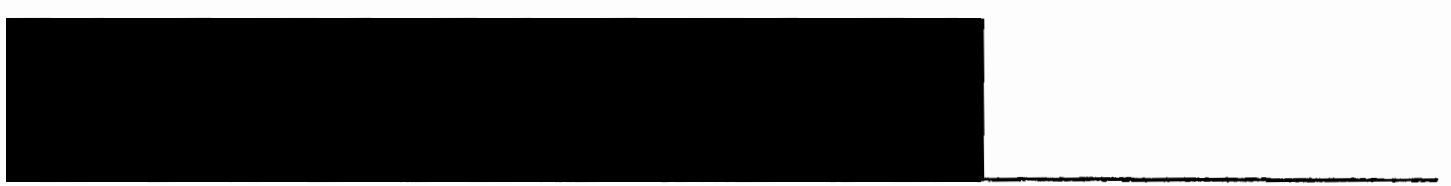

Theodore Grove, Head, Department of Speech Communication

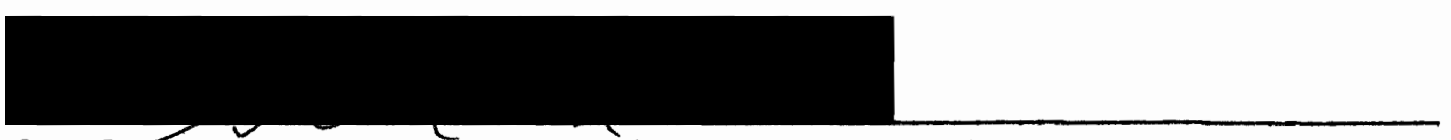

Stanley E. Rauch, Deạn of Graduate Studies and Research 
TABLE OF CONTENTS

PAGE

LIST OF TABLES ................... . .

CHAPTER

I PURPOSE OF THE STUDY. . . . . . . . . . . . . 1

I I DEVELOPMENT OF THE STUDY ............ 5

III RESULTS OF THE STUDY . . . . . . . . . . . . . 7

Nature and Scope of Forensics Programs . . . . 8

Characteristics and Qualifications of

Forensics Directors . . . . . . . 21

Characteristics of Forensics Students . . . . . 27

Conclusion ............. 32

IV SUMMARY OF THE STUDY ......................... 33

V . . . . . . . . . . . . . . . . . 36

VI IMPLICATIONS FOR FURTHER RESEARCH . . . . . . 38

BIBLIOGRAPHY . . . . . . . . . . . . . . . 4 42

APPENDIX . . . . . . . . . . . . . . 44-58

A. 1977 Initial Questionnaire . . . . . . . . 44

B. Letter of Explanation for 1977 Initial

Questionnaire............. 46

C. Questionnaire Recipients ............. 47

D. 1977 Supplemental Questionnaire . . . . . . . 50 
E. Letter of Explanation for 1977 Supplemental

Questionnaire .......... 52

F. 1980 Questionnaire ............ . 53

G. Letter of Explanation for 1980 Questionnaire . . 56

H. GTossary of Forensics Events . . . . . . . 57 


\section{LIST OF TABLES}

TABLE

PAGE

I School Classification .............. 8

II Forensic Instruction .............. 9

II Size of Forensics Programs . . . . . . . . . . 10

IV Forensics Program Budgets . . . . . . . . . . . 12

$\checkmark$ Manner of Financing Forensics Programs . . . . . . . . 14

VI Tournament Participation ............ 16

VII League Tournament Participation . . . . . . . . . 17

VIII O.H.S.S.L. District Tournament Participation . . . . . 18

IX O.H.S.S.L. State Tournament Qualifying Schools . . . . 18

$X$ Goals of a Forensics Program ............. 20

XI Teaching Status of Forensics Directors . . . . . . . 21

XII Education of Forensics Directors . . . . . . . . 22

XIII Classes taught by Forensics Directors . . . . . . . . 23

XIV Experience of Forensics Directors . . . . . . . . 25

XV Compensation Received by Forensics Directors . . . . . 26

XVI Amount of Forensics Compensation .......... 26

XVII Grade and Sex of Forensics Students . . . . . . . . . 27

XVIII Student Participation by Event Category . . . . . . . 29

XIX Student Participation by Speaking Event . . . . . . . 30

XX Selected Comparisons. . . . . . . . . . . 37 


\section{CHAPTER I}

\section{INTRODUCTION}

The importance of speech communication as a curricular part of secondary education in the state of Oregon has increased dramaticalty since the first study of speech education was done in 1943. At that time, Walter Eschebeck (2) noted the minor role of speech in the high school curriculum: By 1967, Bolton (1) pointed out that 90 percent of Oregon secondary schools offered speech courses.

The Oregon Department of Education recognized the importance of speech communication when it adopted minimum competencies for high school graduation in 1975. Of the five communication competencies, one involved speaking skills; and one involved.listening skills. It was left to the individual school districts, however, to establish procedures for implementing these competencies.

Although it appears that speech communication is now an integral part of Oregon secondary education, one unique aspect of speech is still very much in question--forensics. Of the six studies conducted in the last 38 years on speech education in Oregon secondary schools, all either omit or discuss only minimally the nature of forensics as part of speech communication in the schools. Eschebeck (2), in 1943, emphasized the philosophy of speech education and the need for a greater role for speech in the curriculum. In 1951, Padrow (4-p. 34) revealed that $39 \%$ (about 1,250 ) of the Oregon high school students 
participated in forensics contests. No mention is made, however, of whether these contests were speech tournaments. or contests sponsored by service organizations. Newbry (3), in 1954, mentions speech oniy incidentally as a minor aspect of Language Arts in the secondary schools. Schlosser's only reference to forensics in 1955 (5-p. 193) indicates $16.4 \%$ of the secondary schools participate in "Interschool Debate, Public Performance." Smith (6) also makes onty passing reference to forensics in his study of speech education in 1961. Bolton's study of 1967 (1) discusses tournaments, extra-duty compensation, and the number of schools offering forensics courses.

During 1978 and 1979, the Oregon Speech Communication Association compiled information on instructional methods in speech communication courses. A survey was sent to all junior and senior high schools containing questions in 6 areas of competitive speech. For comparison purposes, unfortunately, the results are unacceptable. According to the surveyor, Bob Withycombe, "I have drawn conclusions from the material based on rough averages, and they may not truly reflect the total situation around the state." (7-p. 5)

A11 of these studies illustrate the fact that there is a dearth of contemporary information available on forensics. As a result, many people, both in and outside the educational field, do not know what forensics is; of those who recognize the term, most are not fully cognizant of the nature, scope, and status of Oregon high school forensics programs. 
In spite of this situation, forensics is endorsed by a number of educational groups as a legitimate school program. The Oregon School Activities Association, the Confederation of Oregon School Administrators, and the Oregon School Board Association all list forensics as an approved activity. Unfortunately, an endorsement does not insure understanding of, or survival for, a forensics program. Forensics directors are forced to evaluate and justify the program. at their particular schools.

If high school forensics directors are to fulfill their responsibilities as educators and coaches, however, they must have the material necessary for the evaluation and justification of their programs: This study is an attempt to provide this information. The purpose of the study is fourfold:

A. To compile comprehensive, contemporary data on forensics programs in the State of Oregon,

B. To correlate data for efficient use by forensics directors in the evaluation and justification of their respective programs,

C. To ascertain any relationships which may exist among program characteristics examined in the survey, and

D. To set forth possible hypotheses for further research.

Without adequate data, high school forensics directors are faced with the difficult, if not impossible, task of evaluating the forensics program at their respective schools. A director cannot be expected to evaluate how effective his/her program is in terms of the students involved, funding, and the goals and emphasis of the program without some standard or average to use for comparison. Furthermore, as in 
most areas of education, forensics directors are hard-pressed to justify the expense of their programs before principals, superintendents, and school boards. As a result, forensics often suffers in school budgets. Budget committees; always money-conscious, follow the rule, "If the expense isn't justified, cut it."

This study will allow speech educators to view the current status of forensics in Oregon. This, in turn, will allow them to better plan for the future of Oregon high school forensics as an integral part of speech education in Oregon secondary schools. 


\section{CHAPTER II}

\section{DEVELOPMENT OF THE STUDY}

In order to obtain the necessary information on forensics programs, this writer proceeded to develop the method of study. It was decided that the most uniform means of acquiring necessary information was to utilize a questionnaire. This would be sent to forensics directors in Oregon secondary schools.

Questions used in the questionnaire arose primarily from conversations with coaches. They were asked what types of information about forensics programs they would find useful. Questions used in previous studies were also taken into consideration in the development of the questionnaire. The questionnaire consisted of twelve questions covering the nature and scope of forensics programs, the characteristics and qualifications of forensics directors, and the characteristics of forensics students (see Appendix A). Space was provided for individual comments. This questionnaire was attached to a letter explaining the general purpose of the study (see Appendix B).

In determining which schools would receive the questionnaire, it was necessary to establish the parameters for which this study would function. The following terms are defined to limit the scope of the investigation.

Forensics programs are those competitive speech activities under the direction of a school-appointed director or coach. These 
activities consist of tournaments sanctioned by the Oregon High School Speech League (O.H.S.S.L.). The O.H.S.S.L. is the governing body for high school forensics in the state; any school wishing to compete at the district or state levels must be a member of the league.

Oregon secondary schools are those public schools within the boundaries of the state of Oregon having any of grades 9-12. Private and parochial schools are omitted because they are funded privately and are not restricted in the area from which they draw their students.

This questionnaire was then sent in May of 1977 to those schools belonging to the O.H.S.S.L., which complied with the above definitions. The 115 schools on the 1976-77 0.H.S.S.L. membership list received the questionnaire (see Appendix C).

Schools' responses, particularly those to question $\# 12$, and the individual comments provided the basis for a supplemental questionnaire (see Appendix D). With an accompanying cover letter (see Appendix E), this questionnaire was then sent to those schools responding to the initial survey (see Appendix C).

In May 1980, a modified questionnaire (see Appendix F) was developed by incorporating the questions from the two 1977 questionnaires. This was then sent with a letter of explanation (see Appendix G) to all public high schools which were members of the 0.H.S.S.L. for the 1979-80 academic year (see Appendix C). It is the results from these three questionnaires which have provided the data for the current study. 


\section{CHAPTER III}

\section{RESULTS OF THE STUDY}

One-hundred fifteen initial questionnaires were sent in 1977. Sixty-seven (58.2\%) schools responded. Of these schools, each of which received the supplemental questionnaire, fifty-three (79\%) responded. The 1980 questionnaire was sent to 106 schools, with $58(55 \%)$ responding.

It should be noted that twenty-four schools responded to all three questionnaires. Twenty-five schools responded to both 1977 surveys but not to the 1980 survey. Four schools returned the initial 1977 questionnaire and the one in 1980, and nine schools responded to only the first 1977 survey. Eighteen schools were sent only the 1977 questionnaires, for they were not O.H.S.S.L. members during the 1979-80 school year. Fifteen schools which were not members in 1976-77 did receive 1980 questionnaires; of these, twelve responded. The following discussion is based on the responses from these questionnaires.

THE NATURE AND SCOPE OF FORENSICS PROGRAMS

Each respondent was asked to classify itself as being urban, suburban, or rural in describing the area from which the school drew its students. No criteria were provided for making this determination; each forensics director was to rely on his/her own perceptions. It was felt 
that arbitrary classification or criteria given by this researcher would alter the practical value of the results. School districts traditionally view themselves in relation to 1 ) those districts surrounding them, 2) similar economies in other districts, and/or 3) geographic similarities with other districts. By allowing schools to draw on the common conceptions of their community in making the classification, forensics directors would be able to evaluate the results as the district would be inclined to evaluate them.

\section{TABLE I}

SCHOOL CLASSIFICATION

\begin{tabular}{llll} 
& \multicolumn{1}{c}{ Urban } & Suburban & Rural \\
$1976-77$ & $11(16.4 \%)$ & $19(28.4 \%)$ & $37(55.2 \%)$ \\
$1979-80$ & $12(21 \%)$ & $13(22 \%)$ & $33(56 \%)$
\end{tabular}

The classifications generally concurred with the researcher's own impressions of how each school should be grouped. While the percentages do not fluctuate dramatically between the survey years, part of the difference can easily be attributed to two factors: 1) the change in the schools which did not receive either a 1977 or a 1980 questionnaire, and 2) four schools which changed their classification from the 1977 to the 1980 survey. Two of these schools had different coaches at the time of the 1980 survey, which may account for the change in classification. There is no indication from the questionnaires to account for the change in the other two schools' classification. One can only assume that the directors at all four schools perceived the area from which they drew their students to have changed over the three-year period. 
The greater difficulty lies in explaining the large number of responses from schools classifying themselves as rural in comparison to the number from urban or suburban areas. It is general1y accepted that Oregon is still primarily a rural state, especially outside the Willamette Valley. This, however, does not adequately explain the variation; for a number of schools in areas near other urban or suburban schools did not respond. It is possible that forensics directors were too busy to respond, that they lost the questionnaire, or that they did not wish to provide information on their programs.

The second question asked schools to indicate how forensics was taught at the school.

\section{TABLE II}

\section{FORENSIC INSTRUCTION}

A. Forensics is strictly extra-curricular.

\begin{tabular}{|c|c|c|c|c|}
\hline & Total & Urban & Suburban & Rural \\
\hline $1976-77$ & $16(23.9 \%)$ & $3(4.5 \%)$ & $7(10.4 \%)$ & $6(9 \%)$ \\
\hline $379-80$ & $13(22 \%)$ & $3(5 \%)$ & $1(2 \%)$ & $9(15 \%)$ \\
\hline
\end{tabular}

B. Forensics is incorporated in a general speech class.
$\underline{1976-77}$
$4(6 \%)$
$0(0 \%)$
$2(3 \%)$
$2(3 \%)$
$\underline{1979-80}$
$3(5 \%)$
$0(0 \%)$
$1(2 \%)$
$2(3 \%)$

C. Forensics is an elective speech class.
$\underline{1976-77}$
$46(68.6 \%)$
$7(10.5 \%)$
$10(14.9 \%)$
$29(43.2 \%)$
$\underline{1979-80}$
$43(73 \%)$
$9(16 \%)$
$11(19 \%)$
$22(38 \%)$

Those schools having forensics as strictly an extra-curricular activity show a modest decline between 1976-77 and 1979-80. This 
corresponds to an increase in the number of schools offering a separate forensics course, from $68.6 \%$ in 1977 to $73 \%$ in 1980 . The questionnaire sought to determine if schools offered more than one course in forensics (i.e. Beginning Forensics and Advanced Forensics). Unfortunately, statement $D$ on the questionnaire was not easily interpreted, so some schools did not select it as their response. Statement $C$ on Table II, therefore, represents the total of the responses to both $C$ and $D$ of this question on the questionnaires. There are a number of possible reasons for the increase in the number of schools offering a forensics class. Schools may be increasing their elective offerings; enough students interested in forensics may have justified the class. The school may have hired a director who felt more competent to teach the class, or budget problems may not have been present to prevent the inclusion of the course in the curriculum.

Schools were then asked to indicate the approximate size of the program by the number of participants in forensics at their respective schools.

\section{TABLE III}

\section{SIZE OF FORENSICS PROGRAMS}

\begin{tabular}{lclll}
$1976-77$ & Total & Urban & Suburban & Rural \\
\cline { 1 - 3 } $0-10$ & $17(25.4 \%)$ & $2(3.0 \%)$ & $1(1.5 \%)$ & $14(20.9 \%)$ \\
$11-20$ & $22(32.8 \%)$ & $2(3.0 \%)$ & $7(10.4 \%)$ & $13(19.4 \%)$ \\
$21-30$ & $13(19.4 \%)$ & $5(7.4 \%)$ & $2(3.0 \%)$ & $6(9.0 \%)$ \\
$31-40$ & $13(19.4 \%)$ & $1(1.5 \%)$ & $8(11.9 \%)$ & $4(6.0 \%)$ \\
More than 40 & $1(15 \%)$ & $0(0 \%)$ & $1(1.5 \%)$ & $0(0 \%)$ \\
N/A & $1(1.5 \%)$ & $1(1.5 \%)$ & $0(0 \%)$ & $0(0 \%)$
\end{tabular}


TABLE III (continued)

SIZE OF FORENSICS PROGRAMS

\begin{tabular}{lllll}
$1979-80$ & Total & Urban & Suburban & Rural \\
\cline { 1 - 3 } $11-10$ & $16(27.6 \%)$ & $0(0 \%)$ & $2(3.4 \%)$ & $14(24.2 \%)$ \\
$11-20$ & $25(43.1 \%)$ & $6(10.3 \%)$ & $2(3.4 \%)$ & $17(29.4 \%)$ \\
$21-30$ & $17(18.9 \%)$ & $5(8.6 \%)$ & $4(6.9 \%)$ & $2(3.4 \%)$ \\
$31-40$ & $4(6.9 \%)$ & $1(1.7 \%)$ & $3(5.2 \%)$ & $0(0 \%)$ \\
More than 40 & $0(0 \%)$ & $0(0 \%)$ & $0(0 \%)$ & $0(0 \%)$ \\
N/A & $2(3.4 \%)$ & $2(3.4 \%)$ & $0(0 \%)$ & $0(0 \%)$.
\end{tabular}

It appears that the overall size of forensics squads is decreasing. Between 1977 and 1980, programs having between 31 and 40 students decreased $12.5 \%$; and those having more than 40 students were eliminated completely. Sma11 squads (0-10) and medium-large squads (21-30) remained relatively stable. The difference is primarily seen in the substantial increase of medium-sized programs (11-20). In 1977, 32.8\% of the schools fell in this category; but by $1980,43 \%$ had squads in this range. A major contributor to this increase was the number of rural schools which increased their squads in this range from $35 \%$ in 1977 to $51 \%$ in 1980 . It may be that budget reductions account for the downward trend in the size of forensics squads in all groups. It is also possible that student interest is down, or that directors chose to reduce the size of their squads.

The fourth aspect of forensics programs dealt with the funding of programs--the amount of and manner of financing the programs. Results were included from the 1975-76 school year in examining the amount of forensics budgets. 
TABLE IV

FORENSICS PROGRAM BUDGETS

\begin{tabular}{cllll}
\multicolumn{1}{c}{$1975-76$} & Total & Urban & Suburban & Rural \\
\cline { 2 - 5 }$\$ 0-200$ & $6(9 \%)$ & $1(1.5 \%)$ & $0(0 \%)$ & $5(7.5 \%)$ \\
$201-500$ & $18(26.9 \%)$ & $5(7.5 \%)$ & $3(4.5 \%)$ & $10(14.9 \%)$ \\
$501-1,000$ & $16(23.9 \%)$ & $1(1.5 \%)$ & $8(11.9 \%)$ & $7(10.4 \%)$ \\
$1,001-2,000$ & $12(17.9 \%)$ & $1(1.5 \%)$ & $6(9.0 \%)$ & $5(7.5 \%)$ \\
$2,001-3,000$ & $4(6.0 \%)$ & $1(1.5 \%)$ & $1(1.5 \%)$ & $2(3.0 \%)$ \\
more than 3,000 & $2(3.0 \%)$ & $0(0 \%)$ & $0(0 \%)$ & $2(3.0 \%)$ \\
No answer & $9(11.9 \%)$ & $2(3.0 \%)$ & $1(1.5 \%)$ & $6(9.0 \%)$
\end{tabular}

$\underline{1976-77}$

\begin{tabular}{|c|c|c|c|c|}
\hline $\begin{array}{l}0-200 \\
201-500 \\
501-1,000 \\
1,001-2,000 \\
2,001-3,000 \\
\text { more than } 3,000 \\
\text { No answer }\end{array}$ & $\begin{aligned} 4 & (6 \%) \\
12 & (17.9 \%) \\
14 & (20.9 \%) \\
13 & (19.4 \%) \\
4 & (6.0 \%) \\
3 & (4.5 \%) \\
16 & (23.9 \%)\end{aligned}$ & $\begin{array}{ll}1 & (1.5 \%) \\
3 & (1.5 \%) \\
2 & (3.0 \%) \\
1 & (1.5 \%) \\
2 & (3.0 \%) \\
0 & (0 \%) \\
1 & (1.5 \%)\end{array}$ & $\begin{array}{ll}0 & (0 \%) \\
1 & (1.5 \%) \\
8 & (11.9 \%) \\
5 & (7.5 \%) \\
1 & (1.5 \%) \\
1 & (1.5 \%) \\
3 & (4.5 \%)\end{array}$ & $\begin{aligned} 3 & (4.5 \%) \\
8 & (11.9 \%) \\
4 & (6.0 \%) \\
7 & (10.4 \%) \\
1 & (1.5 \%) \\
2 & (3.0 \%) \\
12 & (3.0 \%)\end{aligned}$ \\
\hline
\end{tabular}

$\underline{1979-80}$

$\begin{array}{cclll}0-200 & 5(8.6 \%) & 0(0 \%) & 0(0 \%) & 5(8.6 \%) \\ 201-500 & 5(8.6 \%) & 0(0 \%) & 0(0 \%) & 5(8.6 \%) \\ 501-1,000 & 14(24.1 \%) & 2(3.4 \%) & 3(5.2 \%) & 9(15.5 \%) \\ 1,001-2,000 & 11(19.0 \%) & 4(6.9 \%) & 3(5.2 \%) & 4(6.9 \%) \\ 2,001-3,000 & 14(24.1 \%) & 3(5.2 \%) & 5(8.6 \%) & 6(10.3 \%) \\ \text { more than 3,000 } & 3(5.2 \%) & 0(0 \%) & 1(1.7 \%) & 2(3.4 \%) \\ \text { No answer } & 6(10.3 \%) & 3(5.2 \%) & 1(1.7 \%) & 2(3.4 \%)\end{array}$

Analysis of the results is hampered by the large percentage of schools which did not respond for the 1976-77 school year. If one considers all three years together, however, a distinct shift is noted. Schools are improving their budgets; budgets are being established more in the middle three ranges, from $\$ 500.00$ to $\$ 3,000.00$, rather than in the extreme categories. This may be attributed to a stabilization of programs or to the effects of inflation. 
A school-by-school analys is of the 1975-76 and 1976-77 budgets revealed that $52.2 \%$ of the schools stayed in the same range over the two years; $13.4 \%$ had the budget amount increased, and $2.3 \%$ showed a decrease. Thirty-one and three tenths percent (37.3\%) of the schools responded to only one of the two years surveyed.

Between the 1976-77 and 1979-80 school years, however, a dramatic shift appears to have occurred. Less than one-half of the schools. chose not to respond in 1980 as did in 1977. At the same time, the number of schools budgeted at $\$ 201-\$ 500$ dropped $9: 3 \%$. With only minor changes seen in given ranges $(\$ 0-200, \$ 1,001-2,000$, and more than $\$ 3,000)$, these decreases may correspond to an $18.1 \%$ increase in the schools in the $\$ 2,001-\$ 3,000$ bracket.

A comparison was also made of those twenty-eight schools responding to both the 1977 and 1980 surveys. Specific responses from nine schools (32.15\%) did not allow for comparison. Nine schools (32.15\%) indicated an increase in their budgets, and ten schools (35.7\%) retained essentially the same budgets. No school indicated a decrease in the amount budgeted for forensics.

The questionnaire did not specifically attempt to ascertain the reasons for changes in budgets. It may be that the number of students involved in forensics increased, or that budget pressures on the schools lessened. One school that indicated a decrease between the 1975-76 and 1976-77 school years attributed this to the defeat of a budget levy by voters and the subsequent closure of the school. By the 1979-80 school year, this institution showed an increase over even the 1975-76 budget amount. Possibly, the mere fact of increased 
costs necessitated budget increases just to maintain the same level of the program.

Funding was also examined in terms of the manner of financing forensics. In the following table, the first number indicates those schools receiving funds from the given source; the number in parentheses represents the average percentage of funds those schools receive, and the number in quotes shows the average percentage for all schools in that classification.

\section{TABLE $V$}

MANNER OF FINANCING FORENSICS PROGRAMS

\section{$\underline{1976-77}$}

District monies

Student activities monies

Fund raising

$N A$

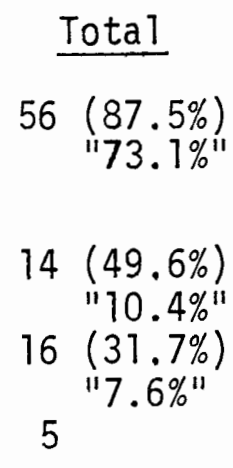

$\underline{1979-80}$

District monies

Student activities monies

Fund-raising

NA

$43(77.9 \%)$
$" 57.8 \% "$
$19(63.3 \%)$
$" 29.7 \% "$
$21 \quad(30.6 \%)$
$" 11.2 \% "$

6

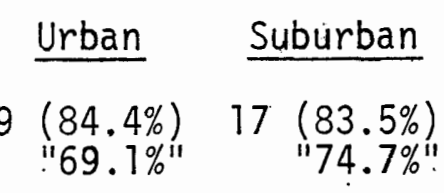

Rurat $30 \underset{\text { "1 }}{(90.63 .5 \%)}$
$2(35 \%)$ "6.4\%"
$4(42.5 \%)$
0
$5(30 \%)$ "7.9\%"
$9(25.6 \%)$
1
$\begin{array}{ll}7 & (67.9 \%) \\ & 112.8 \% " 1 \\ 3 & (35.7 \%) \\ & " 2.9 \% " \\ 4 & \end{array}$

$27(78.9 \%)$ "64.5\%"

$8(64.1 \%)$ "15.5\%"

$15(30.7 \%)$ "13.7\%"

2

The percentage of forensics budgets provided by school district monies showed a significant decrease for the years surveyed, down $15.3 \%$ from $73.1 \%$ in 1977 . This decline is accounted for, in part, by the decrease in the number of schools' programs financed entirely by district 
monies. These fell from $56.7 \%$ of the schools in 1977 to $32.7 \%$ in 1980. The difference appears to have been made up largely by the use of student activities monies. This source of funds increased $10.3 \%$ to provide $20.7 \%$ of forensics budgets in 1980 . It is interesting to note that the number of schools funded entirely in this manner increased dramatically during this time period, from $4.5 \%$ in 1976-77 to $.12 .11 \%$ of the schools in $1979-80$. No schools indicated another source of income for 1976-77 other than those provided on the questionnaire, but in 1980, one school indicated that $5 \%$ of its budget came as a donation from the Mothers' and Dads' Club of the school. One may hypothesize that the taxpayers' revolt and the general economy are being felt by forensics programs. It may also be that state or federally-mandated programs requiring funding are siphoning money from forensics. Unfortunately, as funds for activities are cut back, students must resort to raising funds on their own. But as more groups solicit funds where the dollars aren't available due to the economy, the success of fund-raising activities is minimized. Hence, money generated by the school (i.e. the sale of student body cards) is needed to make up the difference.

The remaining aspects under the nature and scope of forensics programs were surveyed by the supplemental questionnaire in 1977 and by the 1980 questionnaire. Fifty-three schools (8 urban, 16 suburban, 29 rura1) responded to the supplemental questionnaire. This will explain the change in figures from previous discussions.

Since forensics is a competitive activity, schools were queried on their participation in forensics tournaments. 


\section{TABLE VI}

TOURNAMENT PARTICIPATION

Total Urban Suburban Rural

1976-77 №. Avg. №. Avg. №. Avg. №. Avg. $\begin{array}{lllllllll}\text { college-sponsorèd } & 201 & 3.79 & 35 & 4.37 & 87 & 5.44 & 79 & 2.72\end{array}$ high schoolsponsored

$341 \quad 6.43$

$58 \quad 7.25$

1298.06

$154 \quad 5.31$

$\underline{1979-80}$

$\begin{array}{llllllllll}\text { college sponsored } & 266 & 4.59 & 69 & 5.75 & 79 & 6.10 & 118 & 3.57\end{array}$ high schoolsponsored

$\begin{array}{llll}288 & 4.97 \quad 70 \quad 5.80\end{array}$

$\begin{array}{llll}72 & 5.5 & 146 & 4.4\end{array}$

During the 1976-77 school year, Oregon high schools attended an average of 10.22 tournaments, 3.79 college-sponsored and 6.43 high school-sponsored. By 1979-80, schools participated in slightly fewer tournaments, an average of 9.56. Several reasons could be cited for this decline. Increased costs of attending tournaments may have forced schools to reduce the number of tournaments they attend, even if they had budget increases. School districts have also been setting mileage limitations which may have prevented schools from attending some meets.

While the overall number of tournaments attended decreased, particularly in the area of high school-sponsored tournaments, the number of college-sponsored tournaments attended showed an increase. A number of factors could have contributed to this increase. First, some schools interpreted college-sponsored and high school-sponsored differently. Some indicated that if the tournament was held on a college campus, they considered it a college-sponsored tournament; others made the determination based on the organization hosting the tournament. Second, several colleges began hosting tournaments, thus affording more opportunities 
for participation by schools. Third, some schools, which had not attended particular college tournaments for various reasons, once again began attending those tournaments. Fourth, when faced with decision of which tournaments to attend, some directors may have felt that larger college tournaments provided a better caliber and range of competition as opposed to smaller, high school-sponsored tournaments.

Schools were also asked if they participated in a league-sponsored tournament (Wilco, Metro, etc.) other than the O.H.S.S.L. tournaments. Participation here showed a significant increase between 1977 and 1980.

\section{TABLE VII}

LEAGUE TOURNAMENT PARTICIPATION

\begin{tabular}{|c|c|c|c|c|}
\hline $1976-77$ & Total & Urban & Suburban & Rural \\
\hline $\begin{array}{l}\text { Yes } \\
\text { No }\end{array}$ & $\begin{array}{ll}31 & (58.49 \%) \\
22 & (41.51 \%)\end{array}$ & $\begin{array}{l}8(100 \%) \\
0(0 \%)\end{array}$ & $\begin{array}{l}9(56.25 \%) \\
7(43.75 \%)\end{array}$ & $\begin{array}{l}14(48.28 \%) \\
15(51.72 \%)\end{array}$ \\
\hline 1979-80 & Total & Urban & Suburban & Rural \\
\hline $\begin{array}{l}\text { Yes } \\
\text { No }\end{array}$ & $\begin{array}{ll}42 & (72.41 \%) \\
16 & (27.59 \%)\end{array}$ & $\begin{aligned} 11 & (91.67 \%) \\
1 & (8.33 \%)\end{aligned}$ & $\begin{array}{ll}9 & (69.23 \%) \\
4 & (30.77 \%)\end{array}$ & $\begin{array}{l}22(66.67 \%) \\
11(33.33 \%)\end{array}$ \\
\hline
\end{tabular}

Between 1977 and 1980, participation in a league-sponsored tournament increased $13.92 \%$, from $58.49 \%$ to $72.41 \%$. Part of this increase may be due to the sharply rising costs of transportation. Leaguesponsored tournaments draw participants from a limited area, thus saving schools the expense of long trips. This would be especially noticeable among rural schools which are usually farthest away from colleges hosting tournaments. These schools increased their participation by $18.39 \%$. 
The final aspect of tournament participation dealt with 0.H.S.S.L. tournaments, specifically the district and state tournaments.

\section{TABLE VIII}

\section{O.H.S.S.L. DISTRICT TOURNAMENT PARTICIPATION}

$\begin{array}{lllll}1976-77 & \text { Total } & \text { Urban } & \text { Suburban } & \text { Rural } \\ \text { Yes } & 50(94.34 \%) & 8(100 \%) & 16(100 \%) & 26(89.66 \%) \\ \text { No } & 3(5.66 \%) & 0(0 \%) & 0(0 \%) & 3(10.34 \%)\end{array}$

$\underline{1979-80}$

$\begin{array}{lrrrr}\text { Yes } & 54(93.10 \%) & 11(91.67 \%) & 13(100 \%) & 30(90.91 \%) \\ \text { No } & 4(6.90 \%) & 1(8.33 \%) & 0(0 \%) & 3(9.09 \%)\end{array}$

The percentage of schools participating in O.H.S.S.L. district tournaments remained relatively constant, $94.34 \%$ in 1977 and $93.10 \%$ in 1980. This is understandable when one considers that respondents were all members of the O.H.S.S.L., and the principal reason for belonging to this organization is to allow participation at the district and state tournaments. At the same time, there was little change in the schools qualifying students for the 0.H.S.S.L. state tournament. Table IX indicates the number of schools qualifying students and the average number of students each school had at the state tournament (in parenthesis).

\section{TABLE IX}

O.H.S.S.L. STATE TOURNAMENT QUALIFYING SCHOOLS

\begin{tabular}{|c|c|c|c|c|}
\hline & Total & Urban & Suburban & Rural \\
\hline $1976-77$ & $46(4)$ & $8(3.38)$ & $14(4.93)$ & $24(3.67)$ \\
\hline $1979-80$ & $48(5.04)$ & $11(5.45)$ & $13(6.38)$ & $24(4.13)$ \\
\hline
\end{tabular}


It might appear that schools qualified proportionately more students to the state tournament in 1980 than in 1977, but this increase is partially explained by the greater percentage of schools qualifying students in $1977,86.79 \%$ as opposed to $82.75 \%$ in 1980 . Also, two events had been added to the state tournament by 1980 that had not existed in 1977.

The final area to be considered in the nature and scope of forensics programs, but certainly not the last in importance, concerns the goals or objectives of high school forensics programs. On the initial 1977 questionnaire, directors were asked to list what they considered to be the two most important goals of a forensics program. From these responses, a list of ten objectives was compiled and included on the supplemental questionnaire. Directors were then asked to rank these objectives in the order of their importance (1-most important to 10-1east important).

This question was omitted from the 1980 questionnaire: Since most of the coaches were at their respective schools during the period of both surveys, it was felt there would be no significant change in the rank ordering.

Table $X$ shows the ranks of objectives and the percentages of schools placing each in that position. In cases of a tie, the goal having the highest percentage for the lower position was placed in that position. 
TABLE $X$

GOALS OF. A FORENSICS PROGRAM
A) To promote the personal growth of students (i.e. self-confidence)
B) To develop critical thinking abilities in students
C) To provide a non-athletic student activity
D) To improve public speaking skills of students
E) To provide opportunities for students to develop new friendships
F) To succeed in competitive situations
G) To develop ethical communication attitudes in students
H) To promote group participation in an activity
I) To develop research and investigative techniques in students
J) To improve students' abilities as effective communicators

$\begin{array}{rllll} & \text { Total } & \text { Urban } & \text { Suburban } & \text { Rura] } \\ \text { 1) } & \mathrm{A}(52.8 \%) & \mathrm{A}(50 \%) & \mathrm{A}(43.8 \%) & \mathrm{A}(51.7 \%) \\ \text { 2) } & \mathrm{J}(39.6 \%) & \mathrm{J}(25 \%) & \mathrm{J}(56.3 \%) & \mathrm{J}(34.5 \%) \\ 3) & \mathrm{B}(32.1 \%) & \mathrm{G}(37.5 \%) & \mathrm{B}(31.25 \%) & \mathrm{B}(37.9 \%) \\ 4) & \mathrm{I}(20.8 \%) & \mathrm{B}(37.5 \%) & \mathrm{G}(37.5 \%) & \mathrm{D}(20.7 \%) \\ 5) & \mathrm{G}(17.0 \%) & \mathrm{I}(12.5 \%) & \mathrm{D}(18.75 \%) & \mathrm{I}(34.5 \%) \\ 6) & \mathrm{H}(18.9 \%) & \mathrm{H}(25 \%) & \mathrm{H}(18.75 \%) & \mathrm{G}(24.7 \%) \\ 7) & \mathrm{C}(13.2 \%) & \mathrm{C}(12.5 \%) & \mathrm{I}(25 \%) & \mathrm{H}(20.7 \%) \\ 8) & \mathrm{E}(28.3 \%) & \mathrm{F}(37.5 \%) & \mathrm{E}(37.75 \%) & \mathrm{E}(24.1 \%) \\ 9) & \mathrm{F}(22.6 \%) & \mathrm{E}(37.5 \%) & \mathrm{C}(43.75 \%) & \mathrm{F}(27.6 \%) \\ \text { 10) } & \mathrm{D}(3.8 \%) & \mathrm{D}(12.5 \%) & \mathrm{F}(43.75 \%) & \mathrm{C}(34.5 \%)\end{array}$

Schools throughout the state tended to agree on the two most important goals of a forensics program--"to promote the personal growth of students" and "to improve students" abilities as effective communicators". Schools also generally accepted that forensics is not intended to be an activity that stresses competition or socializing, for these goals ( $E$ and $F$ ) were placed in two of the last three places by all groups. Urban schools felt forensics as a non-athletic activity was more important than did suburban and rural schools. The greatest disparity between the areas concerned the goal of improving the public 
speaking skills of students. Urban schools considered this to be least important, while other groups placed it in the upper half of the ranking.

Differences in the rankings could be due to the geographic or economic influences on the program. They might also be the result of the size, competitive success, or budget of the program. The director also may influence the results insofar as he or she is influenced by previous coaches or academic courses taken in preparation for teaching at the high school lever. A discussion of these factors as they relate to forensics directors. follows.

\section{PART II}

\section{CHARACTERISTICS AND QUALIFICATIONS}

OF FORENSICS DIRECTORS

The second part of this study examined the qualifications of forensics directors, their coaching experience, and salaries paid for directing the forensics program. The first question asked whether directors were ful1-time or part-time teachers at their respective schools.

TABLE XI

TEACHING STATUS OF FORENSICS DIRECTORS

$\underline{1976-77}$

Full-time

Part-time

Non-teaching

$\underline{1979-80}$

Ful1-time

Part-time
Total

$50(94.34 \%)$

$2(3.77 \%)$

I $(1.89 \%)$
Urban

$7(87.5 \%)$

$1(12.5 \%)$
Suburban

$16(100 \%)$

$0(0 \%)$

$27(93.10 \%)$

$1(3.45 \%)$

$1(3.45 \%)$

Rural 
The situation appears to have remained fairly stable from 1977 to 1980. The one exception is the non-teaching director in 1977. By 1980, no director was not: engaged in teaching. This would account for the slight upward trend in full-time teaching positions.

The second question considered the academic qualifications of forensics directors. Directors were asked their preparation in speech communication.

TABLE XII EDUCATION OF FORENSICS DIRECTORS

\begin{tabular}{|c|c|c|c|c|}
\hline $1976-77$ & Total & Urban & Suburban & Rura 1 \\
\hline $\begin{array}{l}\text { B.A./B.S. } \\
\text { Master's } \\
\text { Ph.D. } \\
\text { None } \\
\text { Teaching Norm }\end{array}$ & $\begin{aligned} 29 & (54.72 \%) \\
11 & (20.75 \%) \\
0 & (0 \%) \\
6 & (11.32 \%) \\
7 & (13.21 \%)\end{aligned}$ & $\begin{array}{ll}3 & (37.5 \%) \\
5 & (62.5 \%) \\
0 & (0 \%) \\
0 & (0 \%) \\
0 & (0 \%)\end{array}$ & $\begin{aligned} 10 & (62.5 \%) \\
3 & (18.75 \%) \\
0 & (0 \%) \\
2 & (12.5 \%) \\
1 & (6.25 \%)\end{aligned}$ & $\begin{aligned} 16 & (55.17 \%) \\
3 & (10.34 \%) \\
0 & (0 \%) \\
4 & (13.79 \%) \\
6 & (20.69 \%)\end{aligned}$ \\
\hline \multicolumn{5}{|l|}{$1979-80$} \\
\hline $\begin{array}{l}\text { B.A./B.S. } \\
\text { Master's } \\
\text { Ph.D. } \\
\text { None } \\
\text { Teaching Norm } \\
\text { NA }\end{array}$ & $\begin{aligned} 24 & (41.38 \%) \\
10 & (17.24 \%) \\
0 & (0 \%) \\
18 & (31.03 \%) \\
5 & (8.62 \%) \\
1 & (1.72 \%)\end{aligned}$ & $\begin{array}{ll}5 & (41.67 \%) \\
4 & (33.33 \%) \\
0 & (0 \%) \\
2 & (16.67 \%) \\
0 & (0 \%) \\
1 & (8.33 \%)\end{array}$ & $\begin{array}{ll}4 & (30.77 \%) \\
6 & (46.75 \%) \\
0 & (0 \%) \\
2 & (15.38 \%) \\
1 & (7.69 \%)\end{array}$ & $\begin{aligned} 15 & (45.45 \%) \\
0 & (0 \%) \\
0 & (0 \%) \\
14 & (42.42 \%) \\
4 & (12.12 \%)\end{aligned}$ \\
\hline
\end{tabular}

Statewide, formal education in speech communication declined among forensics directors between 1977 and 1980. The sharpest decrease was noted in the category of those with a Bachelor's degree, down $13.34 \%$. A significant increase was also seen in those directors who do not have even a teaching norm in speech ( 15 quarter hours of speech). The number tripled, showing a $19.71 \%$ increase between 1977 and 1980 . 
A number of factors could account for these changes. Directors with advanced degrees in speech have retired or resigned from their positions. Some directors have transferred to other school districts. It is alarming, however, that vacancies apparently are not being filled by those trained in speech. Witness the increase in those directors without a teaching norm in speech. The Oregon Teacher Standards and Practices Commission may have played a major role in this. With the new umbrella "Language Arts" credential, teachers are certified to teach English, Journalism, Drama, and Speech, without having had to take sufficient courses in the latter three to develop expertise. School districts may hire a non-speech major to teach language arts and assign that teacher the forensics program.

With more directors not having degrees or teaching norms in speech communication, it was questioned what classes they taught at their respective schools. Those classes which constitute teaching responsibilities for a double-digit percentage of the forensics directors are provided in Table XIII.

\section{TABLE XIII}

CLASSES TAUGHT BY FORENSICS DIRECTORS

$\begin{array}{lllll}\text { 1976-77 } & \text { Total } & \text { Urban } & \text { Suburban } & \text { Rural } \\ \text { Forensics } & 36(67.92 \%) & 7(63.63 \%) & 10(52.63 \%) & 19(51.35 \%) \\ \text { Speech } & 43(81.13 \%) & 8(72.72 \%) & 14(73.68 \%) & 21(56.76 \%) \\ \text { English } & 37(69.81 \%) & 3(27.27 \%) & 12(63.16 \%) & 22(59.46 \%) \\ \text { Drama } & 9(16.98 \%) & 0(0 \%) & 1(5.26 \%) & 8(21.62 \%)\end{array}$


TABLE XIII (continued)

CLASSES TAUGHT BY FORENSICS DIRECTORS

\begin{tabular}{lcccr}
\multicolumn{1}{c}{$\frac{1979-80}{\text { Total }}$} & $\underline{\text { Urban }}$ & Suburban & Rural \\
Forensics & $39(67.24 \%)$ & $9(75.00 \%)$ & $12(92.37 \%)$ & $18(54.55 \%)$ \\
Speech & $43(74.14 \%)$ & $12(100.00 \%)$ & $10(76.92 \%)$ & $27(63.64 \%)$ \\
English & $35(60.34 \%)$ & $3(25.0 \%)$ & $10(76.92 \%)$ & $22(66.67 \%)$ \\
Drama & $7(12.07 \%)$ & $1(8.33 \%)$ & $0(0 \%)$ & $6(18.18 \%)$
\end{tabular}

It appears that there is little change between 1977 and 1980 in the dominant classes taught by forensics directors. A71 these classes fall under the label "language arts." This would tend to corroborate the supposition that the change in certification requirements has affected forensics programs. Further evidence is provided by the $6.99 \%$ decrease in the number of forensics directors teaching general speech classes. Many school districts have incorporated the state-mandated speaking and listening graduation competencies into the regular English.program and are not offering general speech as often, if at all. Aside from the four principal classes taught in Table XIII, forensics directors taught 5 other courses in 1976-77; one worked as a counselor. By 1980, directors taught classes in ten other areas. Part of this could be due to the state of Oregon permitting teachers to teach two periods a day outside their certified area. Of course, some districts ignore this limit, having a teacher conduct anywhere from 3-5 classes outside his/her area. This writer, while being certified in speech communication, teaches four or five 
general English classes each semester.

The next question examined the coaching experience of forensics directors. Table XIV represents the average number of years of experience of coaches.

\section{TABLE XIV}

EXPERIENCE OF FORENSICS DIRECTORS

\begin{tabular}{|c|c|c|c|c|}
\hline $1976-77$ & Total & Urban & Suburban & Rura 1 \\
\hline $\begin{array}{l}\text { present position } \\
\text { past experience }\end{array}$ & $\begin{array}{l}5.13 \\
1.81\end{array}$ & $\begin{array}{l}4.56 \\
1.5\end{array}$ & $\begin{array}{l}6 \\
2.44\end{array}$ & $\begin{array}{l}4.82 \\
1.55\end{array}$ \\
\hline
\end{tabular}

$\underline{1979-80}$

present position

The results indicate a number of changes having occurred between 1977 and 1980. The average number of years in their present position shows little change from 5.13 years in 1977 to 5.23 years in 1980 . This would indicate that a significant number of directors had hired for their position since 1977. In fact, in 1977 , only $20.8 \%$ were in their first year of coaching; but by $1980,29.3 \%$ were first-year coaches. This correlates to the decline in the academic preparation of forensics directors, fewer with advanced degrees and more not having a teaching norm in speech.

The final aspect of forensics directors to be considered was that of compensation for directing the forensics program. Table XV indicates whether or not directors received compensation. 
TABLE XV

COMPENSATION RECEIVED BY FORENSICS DIRECTORS

\begin{tabular}{|c|c|c|c|c|}
\hline $197.6-77$ & Total & Urban & Suburban & Rural \\
\hline $\begin{array}{l}\text { Yes } \\
\text { No } \\
\text { NA }\end{array}$ & $\begin{aligned} 49 & (92.45 \%) \\
1 & (5.66 \%) \\
1 & (1.89 \%)\end{aligned}$ & $\begin{array}{l}8(100 \%) \\
0(0 \%) \\
0(0 \%)\end{array}$ & $\begin{aligned} 14 & (87.5 \%) \\
1 & (6.25 \%) \\
1 & (6.25 \%)\end{aligned}$ & $\begin{aligned} 27 & (93.10 \%) \\
2 & (6.90 \%) \\
0 & (0 \%)\end{aligned}$ \\
\hline
\end{tabular}

$1979-80$

$\begin{array}{lrrrr}\text { Yes } & 54(93.10 \%) & 12(100 \%) & 13(100 \%) & 29(87.88 \%) \\ \text { No } & 4(6.90 \%) & 0(0 \%) & 0(0 \%) & 4(12.12 \%)\end{array}$

The number of directors receiving compensation remained fairly constant over the period surveyed, $92.45 \%$ in 1977 and $93.10 \%$ in 1980 . The high percentage can probably be attributed to forensics being inciuded in the extra-duty section of teachers' contracts with school districts. This may also account for the change in the amount of compensation received.

TABLE XVI

AMOUNT OF FORENSICS COMPENSATION

1976-77 Total Urban Suburban Rural

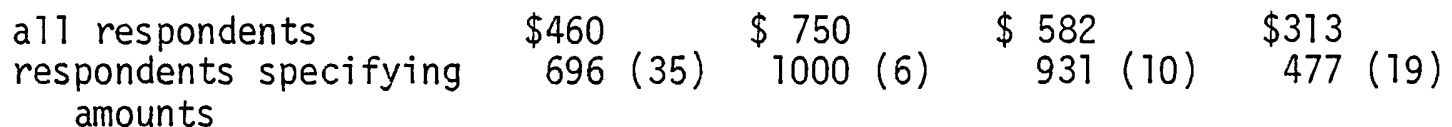

$\underline{1979-80}$

a11 respondents

$671 \quad 871 \quad 999 \quad 470$

respondents specifying $846(46) \quad 1045(10) \quad 1180 \quad 620(25)$ amounts

Many districts now index extra-duty salary schedules, with increases tied to increases in the base salary in the contract. As basic salaries increase, extra-duty salaries increase. 
PART III

CHARACTERISTICS OF FORENSICS STUDENTS

The study finally considered the participants in forensics programs--the students themselves. The first question asked schools to identify forensics students by sex and grade level.

TABLE XVII

GRADE AND SEX OF FORENSICS STUDENTS

$\underline{1976-77}$

grade nine (m)

grade nine ( $f$ )

grade ten $(m)$

grade ten $(f)$

grade eleven (m)

grade eleven ( $f$ )

grade twelve (m)

grade twe lve ( $f$ )
Total

$51(4.39 \%)$

$86(7.39 \%)$

$143(12.29 \%)$

$199(17.11 \%)$

$153(73.16 \%)$

$227(79.52 \%)$

$141(12.12 \%)$

$163(14.02 \%)$
Urban

$10(.86 \%)$

$19(1.63 \%)$

$17(1.46 \%)$

$23(1.98 \%)$

$20(1.72 \%)$

$40(3.44 \%)$

$20(1.72 \%)$

$26(2.23 \%)$
Suburban

Rural

$\begin{array}{lll}32(2.75 \%) & 9(.77 \%) \\ 56(4.82 \%) & 11(.95 \%) \\ 58(4.99 \%) & 68(5.85 \%) \\ 97(8.34 \%) & 79(6.79 \%) \\ 48(4.13 \%) & 85(7.31 \%) \\ 73(6.28 \%) & 114(9.80 \%) \\ 48(4.73 \%) & 73(6.28 \%) \\ 52(4.47 \%) & 85(7.31 \%)\end{array}$

$1979-80$

grade nine (m)

grade nine ( $f$ )

grade ten (m)

grade ten ( $f$ )

grade eleven ( $m$ )

grade eleven ( $f$

grade twelve (m)

grade twelve ( $f$ ) $\therefore 47(4: 56 \%)$

$72(6.99 \%)$

$121(11.75 \%)$

$153 \cdot(14.85 \%)$

$150(14.56 \%)$

$194(18.83 \%)$

$141(13.69 \%)$

$152(14.76 \%)$

$\begin{array}{ll}26 & (2.52 \%) \\ 21 & (2.04 \%) \\ 26 & (2.52 \%) \\ 33 & (3.20 \%) \\ 43 & (4.17 \%) \\ 42 & (4.08 \%) \\ 39 & (3.79 \%) \\ 42 & (4.08 \%)\end{array}$

$10(.97 \%)$

$26(2.52 \%)$

$46(4.47 \%)$

$59(5.73 \%)$

$48(4.66 \%)$

$52(5.05 \%)$

$45(4.37 \%)$

$43(4.17 \%)$
$11(1.07 \%)$

$25(2.43 \%)$

$49(4.76 \%)$

$61(5.92 \%)$

$59(5.73 \%)$

$100(9.71 \%)$

$57(5.53 \%)$

$67(6.50 \%)$

While it may appear that the number of students involved in forensics declined from 1977 (1163 students) to 1980 (1030 s.tudents), this difference is due largely to the nine fewer schools responding to the 1980 questionnaire. By examining the average number of students per school, a very modest increase is noted, from 17.3 students in 1976-77 to 17.7 students in 1979-80. 
The survey did not distinguish between junior high schools (up to grade 9), mid-high schools (grades 9 and 10), and 2, 3, and 4-year senior high schools. Some schools aliso restrict participation in forensics to tenth graders and up. These two factors may account for the great disparity between the number of ninth grade students and the other three grade levels.

Girls tended to dominate the ranks of forensics students at all grade levels in both 1977 and 1980. Girls represented $58.04 \%$ of al1 students in 1977 and $55.44 \%$ in 1980. Although this still indicates a substantial majority of girls in forensics, it does show that the number of boys participating in forensics is increasing, a $2.6 \%$ increase between 1977 and 1980. This dominance by girls could be due to the relationship between forensics and English in the correct usage of grammar and writing. Girls, in the past, have scored higher in verbal skills on standardized tests on the average; hence, they may choose subjects to be involved with which emphasize these skills, such as forensics. Another factor could be linked to the fact that forensics is non-athletic. In the minds of some male students, forensics may be considered not "macho" enough or only for "the brains" of the school.

Forensics is generally divided into two categories--debate and individual events. The next question sought to determine the percentage of forensics students who participate in either or both of these categories. The number in parentheses in Table XVIII represents the number of schools which have $100 \%$ of their students involved in that category. 
TABLE XVIII

\section{STUDENT PARTICIPATION BY EVENT CATEGORY}

\begin{tabular}{lccccc}
\multicolumn{1}{c}{ 1976-77 } & Total & Urban & Suburban & \multicolumn{1}{c}{ Rural } \\
Debate & $5.66(1)$ & 4.0 & & 1.42 & $8.59(1)$ \\
Individual Events & $70.58(18)$ & $66.25(3)$ & $64.00(3)$ & $75.57(12)$ \\
Both & $23.76(4)$ & $29.75(1)$ & $34.58(2)$ & $15.84(1)$ \\
NA & 8 & 3 & 0 & 5
\end{tabular}

$\underline{1979-80}$

Debate

Individual Events

Both

NA

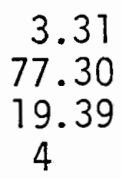

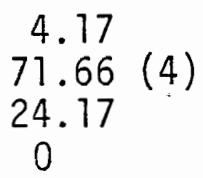

2.45

$55.00(2) \quad 87.42(17)$

42.55

2 schools
9.32

2 schools

By far, the greatest majority of students participated in only individual events. A $6.72 \%$ increase was even noted between 1977 and 1980. This interest in individual events (I.E.'s) could be due to the variety of the events available; it could also be due to a lack of interest in debate, caused by the amount of time debate requires or the cost in supplies and registration fees. An interesting note in these results is the number of schools having $100 \%$ of their students involved in one category. By the 1980 questionnaire, only the I.E. category had any schools with $100 \%$ of the students involved, and this was a $27.78 \%$ increase. Again, this could be attributed to the requirements of participating in debate.

The final question expanded the previous question by determining the number of students participating in specific speaking events. Puppetry was included in the 1977 questionnaire but not on the 1980 form, for efforts to make it a state event had ceased. The move to 
accept Puppetry was largely a one-man attempt, and when he retired from active coaching, other forensics directors decided it wasn't necessary to add another event. During the 1978-79 school year, however, Dramatic Serious and Dramatic Humorous Interpretation were added as state events. Since they were national events, their addition would allow Oregon to send not only the National Forensic League District champion but also the O.H.S.S.L. State champion to the National High School Forensic Tournament in these events. As a result, they were included in the 1980 questionnaire. Appendix $H$ provides an explanation of each eyent. Table XIX indicates the average number of students involved in specific speaking events.

TABLE XIX

STUDENT PARTICIPATION BY SPEAKING EVENT

\section{$1976-77$}

Oxford Debate

Cross $-X$ Debate

Lincoln Douglas Débate

Serious Interpretation

Impromptu

Humorous Inter-

$$
\text { pretation }
$$

Extemporaneous

A.D.S.

Expository

Oratory

Radio Commentary

Poetry
Total

$3.09(8.7 \%)$

$2.92(7.7 \%)$

$1.41(3.7 \%)$

$6.05(15.8 \%)$

$2.20(5.8 \%)$

$4.84(12.7 \%)$

$2.11(5.5 \%)$

$2.22(5.8 \%)$

$3.92(10.3 \%)$

$3.14(8.2 \%)$

$2.81(7.4 \%)$

$3.45(9.0 \%)$
Urban

$3.78(8.3 \%)$

$3.0(6.6 \%)$

$2.67(5.9 \%)$

$6.89(15.1 \%)$

$2.78(6.1 \%)$

$4.33(9.5 \%)$

$2.71(4.6 \%)$

$1.89(4.7 \%)$

$4.22(9.3 \%)$

$4.00(8.8 \%)$

$4.89(10.7 \%)$

$5.0(11.0 \%)$
Suburban

$4.67(8.9 \%)$

$5.22(9.9 \%)$

$2.16(7.4 \%)$

$7.78(6.7 \%)$

$1.89(3.6 \%) \quad .86(2.9 \%)$

$7.94(15.7 \%)$

$4.92(16.7 \%)$

$3.44(6.6 \%)$

$1.46(5.0 \%)$

$6.78(12.9 \%) \quad 4.03(13.7 \%)$

$3.83(7.3 \%) \quad 1.27(4.3 \%)$

$2.72(5.2 \%)$

$2.05(7.0 \%)$

$5.17(9.8 \%)$

$3.25(11.0 \%)$

$3.89(7.4 \%)$

2.57

$(8.7 \%)$

$2.83(5.4 \%)$

$4.11(7.8 \%)$

$2.30(7.8 \%)$

$2.76(9.4 \%)$ 
TABLE XIX (CONTINUED)

STUDENT PARTICIPATION BY SPEAKING EVENT

1979-80

\begin{tabular}{|c|c|c|c|c|}
\hline $\begin{array}{l}\text { Oxford Debate } \\
\text { Cross }-x \text { Debate }\end{array}$ & $\begin{array}{l}1.24(3.3 \%) \\
3.64(9.7 \%)\end{array}$ & $\begin{array}{l}1.17(2.9 \%) \\
4.92(12.2 \%)\end{array}$ & $\begin{array}{l}3.0(4.7 \%) \\
9.08(14.7 \%)\end{array}$ & $\begin{array}{r}.66(2.2 \%) \\
1.17(4.0 \%)\end{array}$ \\
\hline $\begin{array}{l}\text { incoln-Doug7as } \\
\text { Debate }\end{array}$ & $1.89(3.2 \%)$ & $1.25(3.1 \%)$ & $2.85(4.4 \%)$ & $.59(2.0 \%)$ \\
\hline $\begin{array}{l}\text { Derious Inter- } \\
\text { pretation } \\
\text { cmpromptu }\end{array}$ & $\begin{array}{l}4.47(11.9 \%) \\
2.93(7.3 \%)\end{array}$ & $\begin{array}{l}3.42(8.5 \%) \\
3.50(8.7 \%)\end{array}$ & $\begin{array}{l}6.85(10.6 \%) \\
5.69(8.4 \%)\end{array}$ & $\begin{array}{l}4.45(15.1 \%) \\
1.86(6.3 \%)\end{array}$ \\
\hline $\begin{array}{l}\text { Humorous Inter- } \\
\text { pretation } \\
\text { Extemporaneous } \\
\text { A.D.S. } \\
\text { Expository } \\
\text { Oratory }\end{array}$ & $\begin{array}{l}4.48(11.9 \%) \\
2.98(7.9 \%) \\
1.72(4.6 \%) \\
3.0(8.0 \%) \\
2.72(7.3 \%)\end{array}$ & $\begin{array}{ll}4.33 & (10.7 \%) \\
3.33 & (8.3 \%) \\
1.83 & (4.5 \%) \\
3.08 & (7.6 \%) \\
3.17 & (7.9 \%)\end{array}$ & $\begin{array}{l}6.77(10.5 \%) \\
6.85(10.6 \%) \\
2.62(4.1 \%) \\
3.85(6.0 \%) \\
4.23(6.6 \%)\end{array}$ & $\begin{array}{l}4.14(14.0 \%) \\
1.52(5.1 \%) \\
1.52(5.7 \%) \\
3.00(10.2 \%) \\
2.24(7.6 \%)\end{array}$ \\
\hline $\begin{array}{l}\text { Radio Com- } \\
\text { mentary } \\
\text { Poetry }\end{array}$ & $\begin{array}{l}2.95(7.9 \%) \\
2.92(7.3 \%)\end{array}$ & $\begin{array}{l}3.50(8.7 \%) \\
3.25(8.7 \%)\end{array}$ & $\begin{array}{ll}4.31 & (6.7 \%) \\
3.31 & (5.7 \%)\end{array}$ & $\begin{array}{l}2.52(8.5 \%) \\
2.62(8.9 \%)\end{array}$ \\
\hline Dramatic Seri- & $1.86(5.0 \%)$ & $1.83(4.5 \%)$ & $2.62(4.7 \%)$ & $1.79(6.7 \%)$ \\
\hline $\begin{array}{l}\text { ramatic Humor- } \\
\text { ous }\end{array}$ & $1.62(4.3 \%)$ & $1.75(4.3 \%)$ & $2.38(3.7 \%)$ & $1.45(4.9 \%)$ \\
\hline
\end{tabular}

It is difficult to draw conclusions from the results in debate because students may compete in either Oxford or Cross Examination debate, depending upon which is offered at a particular tournament. The decline in 0xford, however, can especially be attributed to the decline in the number of tournaments offering this style of debate and attempts to eliminate it as a state event. Overal1, students participating in debate showed a 3.3\% decrease between 1977 $(19.5 \%)$ and $1980(16.2 \%)$. This corresponds to the results from the previous question, and it is reasonable to assume the same factors, lack of interest, amount of preparation time, or cost, are the causes for these changes. 
Of the individual events, the manuscript interpretation events, Serious and Humorous, maintained their popularity during both survey years. Extemporaneous and impromptu speaking, while being the least popular in 1977, exhibited the only significant increases for 1980 among the individual events of $2.4 \%$ and $2.0 \%$ respectively. The general reduction in the results over the survey period could be attributed to the inclusion of the two dramatic interpretation events.

A11 speaking events were combined to determine any change in the number of events participated in. No change was noted, with students participating in an average of two events during both 1976-77 and 1979-80.

\section{CONCLUSION}

The results of this study are marked by stabilization and consolidation. Although responses to some isolated questions, such as the amount of money budgeted for forensics, noted dramatic changes between 1977 and 1980, the overall characteristics and practices remained relatively constant. It would seem the forensics programs are maintaining their place in Oregon secondary schools. This, in itself, may be an important discovery. At a time when many curricular, co-curricular, and extra-curricular programs are being curtailed or eliminated at the high school level, forensics programs have not shared the same fate. Funding of forensics has changed, but this has not resulted in a significant change in the nature and scope of forensics programs. 
With forensics programs holding their own against the onslaughts of the "back-to-basics" movement and the taxpayer revolt, one can also detect an overall shift to moderation. By 1980, schools general1y responded in the middle ranges to questions. Fewer schools stood out as being excessively large and/or expensive or excessively small and/or under-financed. This movement toward the middle might be viewed as a tactical change in much the same manner as political personages moderate their views. Find an area where the least opposition exists and the greatest amount of support can be found. It is far easier for a forensics director to build or maintain a program if the end result would be a program which is "average" or "on par" with other programs around the state.

If one were to attempt any extrapolation of the results of this study to predict the future of forensics programs in Oregon secondary schools, the characteristics of stabilization and consolidation would figure prominently. The old saying, "There is safety in numbers," would adequately express the overall pattern for the near future. Forensics programs should be able to maintain their status as long as the economic and educational movements continue to exist. One should not expect any drastic improvement in the size, budget, or activities of forensics programs. Neither should one expect any significant curtailment of programs. Forensics programs in Oregon secondary will be put on "hold" until such time as the situation in the state and country improves. 


\section{CHAPTER IV}

\section{SUMMARY OF THE STUDY}

With the outlook for forensics programs being that of maintaining the status quo, it is reasonable to ask, "What is the status quo?" What have been the results of this stabilization and consolidation? In simpler terms, what is the average high school forensics program?

The results of this study provide the information with which one can develop a composite forensics program, a description of the average forensics program in an Oregon secondary school.

\section{COMPOSITE DESCRIPTION OF AN AVERAGE FORENSICS PROGRAM}

The average forensics program operates in conjunction with a forensics class at the school. Approximately eighteen students participate in the program, two ninth graders ( 1 male, 1 female), five tenth graders ( 2 males, 3 females), six eleventh graders ( 3 males, 3 females), and five twelfth graders (2 males, 3 females). In all probability, these students only participate in the individual events, although two students may compete in debate. The number of students who participate in each event is as follows:

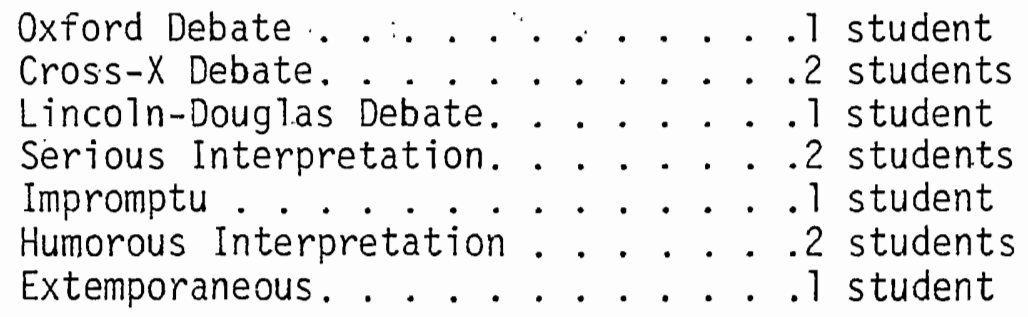




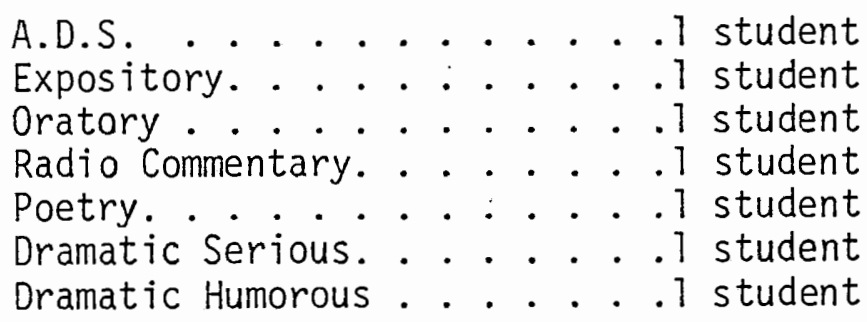

Students compete in two events at each of five high schoolsponsored and four college-sponsored tournaments. Money to allow students to participate in these tournaments comes from a budget of approximately $\$ 2,000.00-\$ 3,000.00$. Sixty-four percent $(\$ 1,280-\$ 1,920)$ of the budget is provided by District monies; twenty-three percent (\$460-\$690) comes from Student activities funds, and thirteen percent $(\$ 260-\$ 390)$ is raised by the students.

Using the forensics budget to participate at tournaments permits the forensics director to realize the goals of the forensics program, the most important one of which is the promotion of the personal growth of students. The least important goal is the improvement of public speaking, even though forensics is a part of speech communication education.

The responsibility for handling the program rests with the forensics director. The director, with a bachelor's degree in speech communication, teaches full-time in the English department at his/her respective school. The director teaches forensics, general speech, and English classes. The director probably began coaching in his/her present position after one year of coaching elsewhere. At the present time, the coach has been at his/her present school for five years. For directing the forensics program, the coach receives $\$ 846.00$ in extra-duty compensation. 
With the exception of coaches increasing the length of time they have been in their present position, this is the kind of forensics program which exists in Oregon secondary schools and will exist for the near future. 


\section{CHAPTER V}

While previous studies discussed only selected aspects of forensics programs in Oregon secondary schools, it is useful to illustrate any changes which have occurred between Padrow's first study in 1951 and this writer's 1980 questionnaire. The following table provides information where comparisons can be made between the 1951 study, Smith's study of 1961, Bolton's study in 1967, and the present study.

TABLE XX

SELECTED COMPARISONS

Number of schools to

which questionnaire was sent

95

1951

1961

1967

$\underline{1980}$

Number of schools responding to questionnaire

70

219

160

58

Percent response

74.0

100.0

91.0

55

Schools offering a forensic course

-- 2

46

42

Percent of schools offering a forensic course

Percent of schools participating in tournaments

Ayerage number of tournaments attended 
In those areas where comparisons are possible, improvements can be noted in the state of forensics programs. Two and one-half times the percentage of schools offered a forensics class in 1980 as did in 1966. This could be due to an increase in the number of students interested in forensics at schools, thereby justifying a class.

The average number of tournaments increased by 2.85 tournaments between 1966 and 1980. Increased budgets may have allowed schools to attend more tournaments. It may be that more tournaments were available for more schools to attend.

The substantial increase in the amount of compensation for forensics can be directly linked to the effectiveness of teachers' associations in negotiating contracts which involve salaries.

Unfortunately, the lack of information and studies on forensics programs makes further comparisons impossible. 


\section{CHAPTER VI \\ IMPLICATIONS FOR FURTHER RESEARCH}

This study provides extensive information on the nature and characteristics of forensics programs in Oregon secondary schools. But like many studies, this information generates many questions for which answers are not provided. These questions, in themselves, would provide the bases for additional studies.

The apparent holding pattern of forensics programs provides an excellent opportunity to search for the answers to these questions. The answers should improve the understanding by educators of the relationship of forensics to speech education and a general language arts education in secondary schools.

The following implications for further research are phrased as questions. They focus on the possible and/or probable causes. for some of the results of this study.

I. Is there any difference in how students, forensics directors, administrators, school board members, and the general public perceive the goals or objectives of a forensics program?

Each of these groups has some influence over forensics programs, in curriculum development, personnel and salary policies, or budget determination. The opinions these groups hold and their relative influence can decide whether forensics is "a frill" or an integral part of the educational program. Where groups can agree on the purposes of forensics, the program may have the financial and community support 
necessary to exist and grow. Where these groups disagree on the goals, lack of student interest, unqualified or unconcerned directors, "shoestring" budgets, or the actual demise of the forensics program may result. Knowing how these groups feel about forensics is also the first step in any endeavor to improve a forensics program, for one might have to change influential opinions in order to bring about the desired changes. In short, all aspects of a forensics program are dependent upon the perceptions of various interest groups to some degree.

II. To what extent does the forensics director influence the emphasis of the forensics program in terms of speaking events participated in by students?

Year after year, schools are labelled as "debate", or "interp." or "oratory" teams, to be watched and feared by schools without these labels. From this writer's experience, these labels seem to be consistently given to the same schools. Do forensics directors actualiy stress particular speaking events? They may spend more time teaching those events they competed in themselves or enjoy more. Several coaches have remarked that they do just this. If this is so, is it a situation that needs correcting? One could also wonder if a coach's preference, positive or negative, could affect a student's performance in a given event. The possibility of a forensic director influencing the actual choice of speaking events by. students and the quality of their performance exists; the real question is, "To what extent?"

III. What factors contribute to the amount of time forensics directors and students devote to forensics? 
Like most competitive activities, to be successful in forensics requires a great deal of practice. There may be a correlation between tournament success and the amount of time devoted to preparation and performance. But not a11 coaches or students spend the same amount of time on forensics. Why do some forensics directors and students spend more time outside the regular school day on forensics? Attitudes toward forensics may influence the time. Personal satisfaction, monetary compensation, or tournament success could also determine how much time a person devotes to forensics. Knowing what factors contribute to the amount of time forensics directors and students devote to forensics may ultimately help to determine what correlation exists between time and tournament success.

IV. What is the relationship, exactly, of forensics to general speech education and language arts education?

For thirty years, it has been assumed that forensics is a part of speech education. More recentiy it has been placed under the umbrella term, language arts. Unfortunately, there exists no concise explanation of the relationship that supposediy exists between forensics and these areas. This is why some schools consider forensics a "frill", and others give it a high priority. When the current period of stabilization and consolidation for forensics programs ends, directors will need more to justify the existence of their programs than just the statement, "Other schools also have forensics." An investigation of forensics as a means of utilizing or improving language arts skills in reading, writing, and speaking would allow forensics directors to demonstrate the value of their programs. There would be far less opportunity for criticisms to arise questioning the validity of forensics. 
V. What factors contribute to the size of forensics programs?

If one examines the number of students involved in forensics at various schools, it is interesting to wonder why a school has a particular-sized program? Does the enrollment of the school affect the size of the program? To what extend do the director's personality and policies determine the number of students involved in forensics? Does the number of types of school activities available to students influence the size? The answers to these questions may allow better predictions when planning budgets or when hiring a new forensics director.

Further research will provide the information necessary to understand the role of forensics in Oregon secondary schools. The relationship of forensics and language arts can be clarified, allowing for better evaluations and planning. While much may be known about forensics, much more needs to be discovered about the nature, scope, and characteristics of forensics programs in Oregon secondary schools. 


\section{BIBLIOGRAPHY}

1. Boiton, Gordon; "A Survey and Analysis of the Existence and Extent of Speech Education in the High Schools in the State of Oregon"; unpublished M.A. thesis, Department of Speech, Pacific University, 1967.

2. Eschebeck, Waiter; "A Study of Speech Education as a Basic Part of the Curriculum for Oregon High Schools"; unpublished M.A. thesis, School of Education, University of Oregon, 1943.

3. Newbry, Burton Cecil; "An Investigation of the Practices and Policies of Teaching the Language Arts in the Secondary Schools of Oregon"; unpublished Doctoral dissertation, School of Education, University of Oregon, 1954.

4. Padrow, Ben; "A Study of Speech Education in the Secondary Schools of Oregon"; unpublished M.S. thesis, Department of Speech, University of Oregon, 1951.

5. Schlosser, William: "An Investigation of the Practices and Policies of Teaching Drama, Journalism, Radio, and Speech in the Public Elementary, Junior High Schools, and Senior High Schools in the State of Oregon"; unpublished Doctoral dissertation, School of Education, University of Oregon, 1955.

6. Smith, James; "Speech Arts Education in Oregon High Schools, 1961 "; unpublished M.A. thesis, Department of Speech, University of Portiand, 1962.

7. Withycombe, Bob; "Oregon Speech Communication Association Survey Results and Speech Class Offerings in Oregon, 1978-1979"; unpub]ished Oregon Speech Communication Association study, 1979. 
SCHOOL NAME

1. Responses may be quoted in the final thesis. Yes No

2. Please send a summary of the results of this survey. Yes NO

3. How would you classify the area from which your school draws its students? (Circle one) URBAN SUBURBAN RURAL

4. Please indicate the type of forensics program at your school.

a. Forensics is strictly an extra-curricular activity.

b. Forensics is included as a unit(s) in a general speech course.

c. Forensics is an elective speech course. Length of course (circle one) 6 wks. $\quad 9$ wks. 18 wks.

36 wks.

Otherwks.

d. Forensics is offered as more than one elective speech course.

5. How many students participate in forensics at your school?
(Circle one)
$0-10$
$11-20$
21-30
$31-40$
more than 40

6. Please indicate the number of students participating in forensics by grade level and sex.

Grade seven Grade eight Grade nine

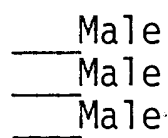
Female Female Female
Grade ten Grade eleven Grade twelve Male Màle Male Female Female Female

7. Please indicate the approximate percentage of students who compete in each of the following categories.

$\%$ OnTy Debate $\%$ Onty Individual Events
$\%$ Debate and one or more Ind. Events

8. Please indicate the number of students participating in each of the following events.

Oxford Debate

- Lincoln-Douglass Debate

- Cross-Examination Debate

- Serious Interpretation Impromptu Speaking

- Radio Commentary

- Poetry Interpretation
Humorous Interpretation

Extemporaneous Speaking After-Dinner Speaking

Expository Speaking

Oratorical Speaking

Puppetry 


\section{APPENDIX A}

1977 INITIAL QUESTIONNAIRE (CONTINUED)

9. How is forensics funded at your school? Please indicate the approximate percentage.

\% School district budget monies (earmarked for forensics)

$\%$ School budget monies (earmarked by the school for forensics)

$\%$ Student Activities monies

Forensics fund-raising monies

$\%$ Other (PJease specify)

10. Please indicate your forensics budget by circling the appropriate amount.
1975-76
$\$ 0-\$ 200$
$\frac{1976-77}{\$ 0-\$ 200}$
$\$ 201-\$ 500$
$\$ 201-\$ 500$
$\$ 501-\$ 1,000$
$\$ 501-\$ 1,000$
$\$ 1,001-\$ 2,000$
$\$ 1,001-\$ 2,000$
$\$ 2,001-\$ 3,000$
$\$ 2,001-\$ 3,000$
more than $\$ 3,000$
more than $\$ 3,000$

11. Please list what you feel are the two most important goals or objectives of the forensics program at your school.

1.

2.

12. Please list any questions which you would like to have answered regarding high school forensics programs.

13. COMMENTS 


\author{
APPENDIX B \\ LETTER OF EXPLANATION \\ FOR 1977 INITIAL QUESTIONNAIRE
}

May 6, 1977

Dear Forensics Director,

My name is Gregg Sylvester. I am a graduate teaching assistant in speech communication at Portland State University. As part of my Master's thes is research, I am conducting a survey of forensics programs in Oregon secondary schools.

This is the first comprehensive study of forensics to be done in the state, and so your assistance is vital to the success of this endeavor. Enclosed you will find a questionnaire dealing with forensics programs. PTease take a few minutes to answer the questions and return the form to me. Your answers will provide the basis for a supplemental questionnaire to be sent to all participating schools at a later date. Please return the questionnaire to me no later than MAY 23, 1977.

Your answers will remain confidential unless you consent to having your responses quoted in the final thesis. You will find a space on the questionnaire to indicate your desire in this regard.

A summary of the results of this survey will be sent to you upon request. Check the appropriate box on the questionnaire.

Thank you for your prompt attention in this matter.

$$
\begin{aligned}
& \text { Respectful7y yours, } \\
& \text { Gregg T. Sylvester } \\
& 401 \text { S.E. 30th } \\
& \text { Portland, Oregon } 97214
\end{aligned}
$$

P.S. PLEASE RETURN YOUR QUESTIONNAIRE BY MAY 23, 1977. A SELF-ADDRESSED, STAMPED ENVELOPE IS INCLUDED FOR YOUR CONVENIENCE. 


\section{APPENDIX C}

\section{QUESTIONNAIRE RECIPIENTS}

1--sent 1977 initial questionnaire

2--responded to initial questionnaire and sent supplemental questionnaire

3--responded to supplemental questionnaire

4--sent 1980 questionnaire

5--responded to 1980 questionnaire

$\begin{array}{llll}\text { John Adams HS } & 1,4,5 & \text { Churchill HS } & 1,2,3,4,5 \\ \text { Aloha HS } & 1,4 & \text { Clackamas HS } & 1,2,3,4,5 \\ \text { Ashland HS } & 1,2 & \text { Clatskanie HS } & 1,4,5 \\ \text { Astoria HS } & 1,4 & \text { Cleveland HS } & 1,4 \\ \text { Baker HS } & 4,5 & \text { Columbia HS } & 4 \\ \text { Bandon HS } & 1,2,4,5 & \text { Coquille HS } & 1,2,3 \\ \text { Banks HS } & 1,2,3,4,5 & \text { Corvallis HS } & 1,2,3 \\ \text { Sam Barlow HS } & 1,4,5 & \text { Cottage Grove HS } & 1 \\ \text { Beaverton HS } & 1,4 & \text { Crater HS } & 1,2,3,4,5 \\ \text { Bend HS } & 1,2,3,4 & \text { Crescent Valley HS } & 1 \\ \text { Benson HS } & 1,2 & \text { Dallas HS } & 1,2,3,4,5 \\ \text { Bonanza HS } & 1,2,3,4,5 & \text { David Douglas HS } & 1,4 \\ \text { Butte Falls HS } & 4 & \text { Dayton HS } & 1,2,3,4 \\ \text { Canby HS } & 1,2,3,4,5 & \text { Douglas HS } & 1 \\ \text { Cascade Locks HS } & 4 & \text { Eagle Point HS } & 1,2,3,4,5 \\ \text { Centennial HS } & 1,2,3,4 & \text { Elgin HS } & 1 \\ \text { Central HS } & 1,2,3,4 & \text { Elmira HS } & 1,2,3,4,5 \\ \text { Chiloquin HS } & 1,2,4 & \text { Estacada HS } & 1\end{array}$




\section{APPENDIX C (continued)}

\begin{tabular}{|c|c|c|c|}
\hline Forest Grove HS & $1,2,3,4$ & Lost River HS & $1,4,5$ \\
\hline Frnaklin HS & 1,4 & Madison HS & $1,2,3,4$ \\
\hline Gilchrist HS & 1 & Madras HS. & 1 \\
\hline Gladstone HS & $1,2,4$ & Marshfield HS & 7,4 \\
\hline Grants Pass HS. & $1,2,3,4$ & Mazama HS & 4,5 \\
\hline Gresham HS & $1,2,4,5$ & Mazama Mid HS & $1,2,3$ \\
\hline Henley HS . & $1,4,5$ & McKay HS & 4 \\
\hline Heppner HS & 4,5 & McMinnville HS & $1,2,3,4,5$ \\
\hline Hermiston HS & $1,2,3,4$ & McNary HS & 1,4 \\
\hline Hidden Valley HS & 4,5 & Medford Mid HS & $1,2,3,4,5$ \\
\hline Hillsboro HS & $1,2,3,4$ & Medford Senior HS & $7,4,5$ \\
\hline Hillsboro Mid HS & $1,2,3$ & Milwaukie HS & $1,2,3,4$ \\
\hline Hood River Valley HS & $1,4,5$ & Mollala HS & 4,5 \\
\hline Huntington HS & 1 & Mountain View HS & 4,5 \\
\hline Imbler HS & $1,2,3,4,5$ & Myrtle Point HS & $1,2,3$ \\
\hline Jackson HS & $1,2,4$ & Neah-Kah-Nie HS & $1,2,4,5$ \\
\hline Jefferson HS. & $1,4,5$ & Newberg HS & $1,2,3,4$ \\
\hline Junction City HS & 1,4 & North Bend HS & $1,4,5$ \\
\hline Klamath Union HS & $1,2,3,4,5$ & North Eugene HS & $1,2,3,4,5$ \\
\hline Knappa HS & 1 & North Salem HS & $1,2,3$ \\
\hline LaGrande HS & $1,4,5$ & North Valley HS & 4,5 \\
\hline Lake Oswego & $1,4,5$ & Nyssa HS & $1,2,3,4,5$ \\
\hline Lakeridge HS & $1,4,5$ & Ontario HS & $1,4,5$ \\
\hline LaPine HS & 4,5 & Oregon City HS & $1,2,3,4$ \\
\hline Lebanon HS & 1,4 & Parkrose HS & $1,2,4$ \\
\hline Lincoln HS & 1,4 & Phoenix HS & $1,2,3,4$ \\
\hline
\end{tabular}




\section{APPENDIX C (continued)}

\begin{tabular}{|c|c|c|c|}
\hline Pine Eagle HS & $1,2,4$ & Taft HS & 1,4 \\
\hline Pleasant Hill HS & $1,2,3,4$ & The Dalles. HS & $1,2,3$ \\
\hline Ranier HS & $1,2,3,4,5$ & Tigard HS & $1,2,3,4$ \\
\hline Redmond HS & $1,2,3,4$ & Tillamook HS & $1,2,3,4,5$ \\
\hline Rex Putnam HS & $1,2,3,4,5$ & Umatilla HS & $1,2,3,4$ \\
\hline Reynolds HS & $1,2,3,4$ & Union HS & 4,5 \\
\hline Rogue River HS & 1 & Vale HS & $1,4,5$ \\
\hline Roosevelt HS & $1,2,3,4,5$ & Vernonia HS & 1,4 \\
\hline Roseburg HS & $1,2,4,5$ & Washington HS & $1,2,4$ \\
\hline St. Helens HS. & $1,4,5$ & West Albany HS & $1,2,3,4,5$ \\
\hline Sandy HS & 1,4 & West Linn & 1 \\
\hline Scappoose HS & $1,2,3$ & Wi1lamette HS & 1 \\
\hline Scio HS & 4,5 & Willamina HS & $1,2,3,4$ \\
\hline Seaside HS & $1,2,3,4$ & Wilson HS & 1,4 \\
\hline Sheldon HS & 1,4 & Woodburn HS & $1,4,5$ \\
\hline Sheridan HS & $1,2,4$ & Yamhil1-Carlton HS & $1,2,3,4,5$ \\
\hline Sherwood HS & 4,5 & & \\
\hline Silverton HS & 1,4 & & \\
\hline South Albany HS & 1,4 & & \\
\hline South Eugene HS & $1,4,5$ & & \\
\hline South Salem HS & $1,2,3,4$ & & \\
\hline Sprague HS & $1,2,3,4$ & & \\
\hline Springfield HS & $1,2,3,4,5$ & & \\
\hline Sunset HS & $1,2,3,4,5$ & & \\
\hline Sutherl in $H S$ & $1,2,3,4,5$ & & \\
\hline Sweet Home HS & 1,2 & & \\
\hline
\end{tabular}


SCHOOL NAME

1. What is your teacher status at your school?
Full-Time
Part-Time
Non-Teaching

2. How many classes do you teach each day?

$\begin{array}{ll}\text { Forensics } & \text { General Speech } \\ \text { Science Ether Area(specify)_English__ Social Science }\end{array}$

3. How many years have you directed forensics at your present school? Years

4. How many years had you coached forensics previous to your present position? Years

5. What degree(s) do you hold in Speech Communication?
None B.S. or B.A.
M.A., M.S., M.A.T., or M.S.T. Ph.D.

6. If you do not hold a degree in speech, do you have a teaching norm in speech? Yes No

7. Do you receive "extra duty" pay for coaching forensics? _Yes _ No If so, \$

8. Please indicate the number of forensics tournaments your school participated at during the 1976-77 school year?

College-Sponsored__ High School-Sponsored

9. Did your school participate at a league tournament during 1976-77? Yes No

10. Did your school participate at the 1977 district forensics tournament? Yes No

11. How many students from your school qualified for the 1977 state tournament?

12. Please rank the following objectives in order of your preferences for a high school forensics program. (1-most important, 2-second in importance,...10-least important)
a) To promote the personal growth of students (i.e. self-confidence)
b) To develop critical thinking abilities in students
c) To provide a non-athletic student activity
d) To improve public speaking skills of students
e) To provide opportunities for students to develop new friendships 
1977 SUPPLEMENTAL QUESTIONNAIRE (CONTINUED)

f) To succeed in competitive situations

g) To develop ethical communications attitudes in students

h) To promote group participation in an activity

i) To develop research and investigative techniques in students

j) To improve students' abilities as effective communicators

THANK YOU FOR YOUR ASSISTANCE. 


\section{APPENDIX E \\ LETTER OF EXPLANATION \\ FOR 1977 SUPPLEMENTAL QUESTIONNAIRE}

May 24, 1977

Dear Forensics Director,

I want to thank you for your prompt completion and return of my questionnaire on high school forensics programs. The responses have been most encouraging. I am enclosing a supplemental questionnaire which I would appreciate having you complete and return to me. Many of the questions on this form are based on the suggestions and comments made by forensics directors on the questionnaire I sent to high schools earlier this month. Please take a few moments to complete this form and return it to me by June 11, 1977. I am enclosing a self-addressed, stamped envelope for your convenience.

Again let me thank you for your co-operation in this endeavor. I hope the final results will be of as much benefit to you as they have been to me.

Respectfulty yours,

Gregg T. Sylvester

P.S. REMEMBER: Please complete the form and return it to me by June 11, 1977. 
SCHOOL NAME

A11 responses will be confidential.

1. How would you classify the area from which your school draws its students? (Circle one)

$$
\text { URBAN SUBURBAN RURAL }
$$

2. Please indicate the type of forensics program at your school.

a. Forensics is strictly an extra curricular activity.

b. Forensics is included as a unit(s) in a general speech course.

c. Forensics is an elective speech course. Length of course (circle one) 6 wks. 9 wks. 18 wks. 36 wks. Other wks.

d. Forensics is offered as more than one elective:speech course.

3. How many students participate in forensics at your school?
(Circle one) $\quad 0-10 \quad 11-20 \quad 21-30 \quad 31-40$ more than 40

4. Please indicate the number of students participating in forensics by grade level.

Grade 7

Male

Female

Grade 10

$\mathrm{Male}$

Female

Grade 8 Male Female

Grade 11 Male Fema 1 e

Grade 9 Male Female

Grade 12 Male Fema $7 e$

5. Please indicate the approximate percentage of students who compete in each of the following categories.

$\%$ Only Debate $\%$ Only Individual Events

$\%$ Debate and one or More Ind. Events

6. How is forensics funded at your school? Please indicate the approximate percentage.

$\%$ School budget monies (earmarked for forensics)

$\%$ Student activities monies

$\%$ Forensics fund raising monies

\% Other (Please specify 
APPENDIX F

1980 QUESTIONNAIRE (CONTINUED)

7. Please indicate the number of students participating in each of the following events.

Oxford Debate

- Cross Examination Debate

—_ Impromptu Speaking

__ Extemporaneous Speaking

Expository Speaking

— Oratorical Speaking

- Poetry Interpretation
Lincoln Douglass Debate

Serious Interpretation Humorous Interpretation After Dinner Speaking Dramatic Serious Radio Commentary Dramatic Humorous

8. Please indicate your forensics budget by circling the appropriate amount

$$
\begin{aligned}
& \frac{1979-1980}{\$ 0-\$ 200} \\
& \$ 201-\$ 500 \\
& \$ 501-\$ 1,000 \\
& \$ 1,001-\$ 2,000 \\
& \$ 2,001-\$ 3,000
\end{aligned}
$$

9. What is your teacher status at your school?
Full-Time
Part-Time
Non-Teaching

10. How many classes do you teach each day? Forensics Science General Speech English Social Science Other Area (specify)

11. How many years have you directed forensics at your present school? Years

12. How many years had you coached forensics previous to your present position? Years

13. What degree(s) do you hold in Speech Communication? None B.S. or B.A. M.A., M.S., M.A.T., or M.S.T. Ph.D.

14. If you do not hold a degree in Speech, do you have a teaching norm in speech? Yes No

15. Do you receive "extra duty" pay for coaching forensics? Yes. No If so, \$

16. Please indicate the number of forensics tournaments your school participated at during the 1979-89 school year?

College Sponsored

High School Sponsored 
APPENDIX $F$

\section{QUESTIONNAIRE (CONTINUED)}

17. Did your school participate at the 1980 district forensics tournament? Yes No

18. Did your school participate at a league tournament during 1979-80? Yes No

19. How many students from your school qualified for the 1980 state tournament?

THANK YOU FOR YOUR ASSISTANCE 


\section{APPENDIX G \\ LETTER OF EXPLANATION \\ FOR 1980 QUESTIONNAIRE}

May 8,1980

Dear Speech Coach,

In May of 1977 I conducted a survey of Oregon high school forensics programs as part of my master's thes is at Portland State University. The responses from coaches around the state was extremely helpful in setting up the first part of the thesis. Now I am conducting another survey to gather information for comparison purposes.

I realize this time of year is busy for all of us so your assistance will be greatly appreciated. Please take a few moments of your time to complete the enclosed questionnaire. I have also included a selfaddressed envelope for your convenience. All responses will remain confidential. Please mail the completed questionnaire by May 27, 1980.

I want to thank you beforehand for your effort on my behalf.

Sincerely yours,

Gregg T. Sylvester

Director of Forensics

Hidden Valley High School 


\section{GLOSSARY OF FORENSICS EVENTS}

After-Dinner Speaking--The student chooses his own subject and develops an original speech to entertain. It should have an undertone of seriousness. The speech must be delivered from memory and shal1 not exceed six minutes in length.

Expository Speaking--The student chooses his own subject and develops an original speech to inform. The student may use visual aids, excluding projected images, to supplement the exposition. The speech must be delivered from memory and shall not exceed eight minutes in length.

Extemporaneous Speaking--The student selects three subtopics from the year's topic area and is allowed one hour for preparation. The speech must be delivered from memory and sha11 not exceed seven minutes in length.

Humorous Dramatic Interpretation--The student interprets his own cutting from published printed novels, short stories, plays or poetry. It is to be humorous in nature and in good taste. The student speaks from memory for no more than ten minutes.

Humorous Interpretation--The student interprets his own cutting from either prose or drama. It is to be humorous in nature and in good taste. The student shall read from a manuscript for no more than eight minutes.

Impromptu Speaking--The student selects three subtopics from the year's topic area. The student chooses one and begins speaking immediately without time for preparation. The student shal1 speak for no more than five minutes.

Oratory--The student chooses his own subject and develops an original speech to persuade. The speech must be delivered from memory and shall not exceed eight minutes in length.

Poetry Reading--The student chooses at least three poems, each of which is at least eight lines long. The poems must be related to and organized around a central theme. The student shall read the poems from manuscripts for no longer than eight minutes.

Radio Commentary--The student chooses his own current event and develops an original news commentary. The speech must be read from a manuscript and shall end between 4.45 and 5.15 minutes.

Serious Dramatic Interpretation--The student interprets his own cutting from published printed novels, short stories, plays or poetry. It is to be serious in nature and in good taste. The student speaks from memory for no more than ten minutes. 
Serious Interpretation--The student interprets his own cutting from either prose or drama. It is to be serious in nature and in good taste. The student shall. read from a manuscript for no more than eight minutes.

Cross-Examination Debate--Two students sha11 comprise each team to debate the year's policy resolution. After each student's first speech, an opponent is permitted to directly cross-examine the speaker.

Lincoln-Douglas Debate--One student shall comprise each team to debate the year's policy resolution. After each student's first speech, the opponent is permitted to cross-examine the speaker.

Oxford Debate--Two students shal1 comprise each team to debate the year's policy resolution. No direct cross-examination of speakers is permitted. 